\title{
INCOME INEQUALITY IN OECD COUNTRIES: DATA AND EXPLANATIONS
}

\author{
A B ATKINSON
}

CESIFO WORKING PAPER NO. 881

CATEGORY 10: EMPIRICAL AND THEORETICAL METHODS

FEBRUARY 2003

\begin{abstract}
PRESENTEd AT CESifo CONFERENCE ON GlobaLIZATION, INEQUALITY AND WELL-BEING, NOVEMBER 2002
\end{abstract}

\footnotetext{
An electronic version of the paper may be downloaded

- from the SSRN website:

- from the CESifo website: www.CESifo.de
} 


\title{
INCOME INEQUALITY IN OECD COUNTRIES: DATA AND EXPLANATIONS
}

\begin{abstract}
There is much disagreement about both the facts and the explanations of income inequality. Even if we confine attention to OECD countries, we find people arguing that there has been a great U-turn, with inequality rising sharply after its post war fall, and others who believe that the speed of change is glacial. In order to evaluate the historical record, we need data for a long run of years. The present paper reviews evidence about covering the period 1945-2001 for nine OECD countries. It is widely believed that rising inequality is attributable to technological change and to globalisation. The second part of the paper argues that these are only part of a complex story. Household incomes depend on public policy and on sources of income apart from work. What is happening at the top of the distribution may need to be explained quite differently.
\end{abstract}

JEL Code: H0, E6.

\author{
Anthony B Atkinson \\ Department of Economics \\ Nuffield College \\ Oxford OXI 1NF \\ United Kingdom \\ tony.atkinson@nuffield.ox.ac.uk
}


CESifoRevised

Income Inequality in OECD Countries: Data and Explanations ${ }^{1}$ Tony Atkinson

\section{Introduction}

The debate about globalisation and world inequality has several dimensions, and these are often confused. Some people are concerned with absolute measures of well being and others with relative inequality. Sometimes it is inequality between countries that is the driving force; at other times the key variable appears to be inequality within countries. Changes in income inequality may be attributed to internal structural dynamics (the "Kuznets curve") or to the interdependence of countries ("international division of labour"). It is therefore not surprising that participants in the debate find themselves engaged in controversy and that outside observers find themselves puzzled. This paper deals with just one part of the puzzle: the relative distribution of income within OECD countries. But, in concentrating on inequality within rich countries, I am not leaving controversy behind. There are strong differences of view - both about the facts and about their explanation. These two aspects form the content of the two main sections of the paper.

Section A is concerned with the empirical evidence about income inequality. Many people are firmly convinced that the period of diminishing inequality after the Second World War has come to an end and been replaced by a period of widening differences. Harrison and Bluestone (1988) have christened it

\footnotetext{
${ }^{1}$ Revised version of paper prepared for the CESifo conference on "Globalization, Inequality and Well-Being" in Munich, November 8-9, 2002. I am grateful to the participants at the conference for their most helpful comments, which have led to
} 
the "great U-turn". According to Alderson and Nielsen, "after four decades of moderating inequality, income inequality in the United States began to increase around 1970. Since then it has risen at a steady rate" (2002, page 1246). They go on to suggest that the upswing has an "international character". Cornia and Court describe how "the Golden Age, a period of stable global economic growth between the 1950s and early-mid 1970s, witnessed declines in income inequality in a number of countries (with some exceptions). This trend was reversed over the last two decades as country after country has experienced an upsurge in income inequality" (2001, page 7). In contrast to the "great U-turn" hypothesis stands the belief that there has been little distributional change within countries, supported by a number of studies of the variation of inequality over time. Gustaffson and Johansson find for 16 industrialised countries that "the correlation between the Gini coefficient and the time-variable is almost zero" and that there is only "a weak U-shaped relationship" (1999, page 591). Melchior, Telle and Wiig (2000) conclude that in industrialised and high income developing countries inequality has not on average changed much between 1960 and 1990. On this view, the pace of change is glacial.

There is therefore disagreement about what is to be explained. A quarter century ago, Pen commented, "the great debate on income distribution goes on and on; and not even the facts are beyond dispute. In this age of microdata, computers and Theil coefficients, a straightforward question like: "Has inequality in the developed countries of the West diminished over the last decades?" provokes different answers from different observers" (Pen, 1979, page 682). Today we can say the same about the question as to whether inequality has increased.

significant revisions, and to Professor Gert Wagner for his supplying the most 
Section B is concerned with some of the possible explanations. Here again there are different views. In the field of income distribution, there are many forces at work, and these interact, as is well illustrated by two frequently discussed elements: globalization and the welfare state. In what has become a widely accepted explanation for rising income inequality, these elements have been invoked to explain how a common force (globalization) can have differing effects in different countries depending on the extent of their welfare states.

Globalization and/or technological change have led to a shift in demand away from unskilled labour. The distributional consequences of such a shift depend on the form of the welfare state. Where wages are freely flexible, then the shift in demand causes increased wage dispersion. Where the welfare state provides an effective floor to wages, then the result is unemployment of unskilled workers.

Thus, we have a unified explanation of what is happening in the United States (increased wage premium for skilled relative to unskilled workers) and in Continental Europe (high unemployment). This story is not however fully convincing. As I have argued (Atkinson, 1999), this "Transatlantic Consensus" is open to question. Even on its own terms it is incomplete, and when we step outside the textbook model the conclusions can be rather different. In Section B, I consider the supply response in terms of investment in skills, and the link between factor prices (wages) and the distribution of personal incomes. This both reveals alternative explanations, involving the capital market as well as the labour market, and helps explain differences across countries. Moreover, the conventional theory focuses on unskilled workers and the bottom of the income distribution. In a number of OECD countries, however, it is increased inequality at the top that is 
most evident. In the final part of Section B, I investigate the long-run experience of top income groups in four OECD countries and point to the need for alternative explanations.

\section{A The Empirical Picture}

\section{Issues of Definition}

Inequality of what? Among whom? Measured how? Here my preferred definition is the distribution of disposable annual income among households with total household income being adjusted for household size and/or composition and each household being counted as many times as there are individuals. This choice is open to question. ${ }^{2}$ Money income is only a partial measure of social welfare, and expenditure may be preferred as a measure of standard of living. Inequality of consumption may have risen less than that of income (Krueger and Perri, 2002).

On the other hand, it may be argued that our concern should be with potential rather than actual use of resources. The study of poverty in OECD countries (see Atkinson, 1998) has distinguished between approaches concerned with the standard of living and approaches concerned with the right to a minimum level of resources. ${ }^{3}$ The difference is neatly encapsulated by the fact that the US poverty line used to be lower for women than for men, a difference which was justified in terms of the difference in minimum food requirements, but which clearly could not be justified on a minimum rights basis. One can interpret the move to a

\footnotetext{
${ }^{2}$ These definitional issues are discussed in, among other places, Atkinson, Rainwater and Smeeding (1995), Atkinson and Brandolini (2001), and the Expert Group on Household Income Statistics (2001).

${ }^{3}$ This distinction is relevant to debate about the World Bank's $\$ 1$ a day poverty line, where many commentators assume that standard of living is the sole concern, whereas critics of the World Bank approach may favour a rights-based concept.
} 
uniform scale for men and women as an implicit change in the underlying concept. The revealed preference of governments, via the medium of their statistical agencies, is indeed for the distribution of income, and it is on this definition that I concentrate here.

Differences in definition may affect not only the level of measured inequality but also the change over time. This should be emphasised since there is a tendency to assume that differences in definition can be treated as a fixed effect. Three examples serve to illustrate this point and to underline the limitations of the concept used in the empirical results presented here. The first is the use of annual rather than permanent income. To the extent that annual income exhibits transitory variation that can be offset by borrowing and lending, it overstates inequality of permanent income. It is possible that the economic changes of recent decades have been associated with increased volatility (see Gottschalk and Smeeding, 2000, Section 5, for a review of the limited evidence), in which case the rise in annual income inequality may overstate the rise in permanent income inequality. This would not be captured by a time constant dummy variable. A second example is that the analysis makes no allowance for within household inequality. In the UK, poverty measured on a family unit basis has typically been significantly higher than poverty measured on a broader household basis. It has recently become clear (Webb, 2002) that the difference has declined over time. Poverty among families has increased substantially in the UK but by less than on a household basis. The trend in the two series is different. The third example is the shortfall of measured income from a comprehensive definition. Important sources are typically missing from official statistics, and these change over time. Capital gains, stock options, and remuneration offshore became more important in 
the latter part of the Twentieth Century, leading inequality to be increasingly under-stated. Conversely, tax reductions in a number of OECD countries in the past two decades may have led to a re-arrangement of income, so that more income appears in taxable form. In the US it is argued that there has been a shift from the corporate to the personal tax base (Gordon and Slemrod, 2000). Moreover, countries differ in the degree of comprehensiveness of their income definition, and this will affect the degree to which the changes over time can be compared.

In summarising the extent of inequality in Section A, I make use of the Gini coefficient, which has a graphical interpretation as the ratio of the area between the Lorenz curve and the diagonal to the whole triangle, but which is only one particular way of reducing the whole distribution to a single number. It is perfectly possible for the distribution to change significantly but for the Gini coefficient to remain unchanged. There could be redistributive forces working in different directions at different points. Demographic change could be causing a rise in the proportion of pensioners with relatively low incomes, while at the same time progressive taxation is reducing the shares of top income groups. This is one reason why, in Section B, I turn to looking at the shares of top income groups, which could be moving in a different pattern from the Gini coefficient.

Data

My time frame is the second half of the twentieth century. I believe that the recent inequality movements can only be understood in the light of the historical experience. Indeed, while attention is confined here to the period 19452000, an even longer perspective would be desirable. I also attach considerable weight to high frequency series. Reference to "high frequency" may sound absurd 
when the term is more conventionally applied to weekly or daily financial data.

What I am suggesting here is that where the underlying data are collected annually, then we should use the full set. In particular, I have serious doubts about the practice adopted recently by the OECD (for example; Förster, 2000) of taking single observations for "mid-1970s", "mid-1980s" and "mid-1990s". Such a procedure can misrepresent the dynamic pattern. A single year can be highly misleading.

I have therefore assembled income distribution data for nine OECD countries: ${ }^{4}$ Canada, the UK and the US, Italy, the Netherlands, and West Germany, Finland, Norway and Sweden. As the order of listing indicates, they may be seen as belonging to three groupings: Anglo-Saxon, mainland European, and Nordic countries. I should stress that these data are not comparable across countries. The exercise is different from that conducted by the Luxembourg Income Study, which has very valuably put income distribution data on a broadly comparable basis. Their estimates are however limited to a selection of years. My quest for annual series means that I have to use the estimates produced in the most part independently by official statistical agencies. They reflect particular national features. For example, the official US estimates of the Gini coefficient shown in Figure 1 relate to the distribution of income before tax. In this respect they differ from most other countries.

\footnotetext{
${ }^{4}$ This compilation draws heavily on work with Andrea Brandolini of the Bank of Italy. Brandolini (1998) has data for the pre-war period as well. Among earlier sources with time series covering a range of countries are Atkinson (1997), Atkinson, Rainwater and Smeeding (1995, Chapter 5), Flora et al (1987), Fritzell (1993), Gardiner (1997), Gottschalk and Smeeding (1997 and 2000), Jäntti and Danziger (2000), Kraus (1981), Kuznets (1963), Morrisson (2000), Roberti (1974), Sawyer (1976), and Stark (1977).
} 


\section{The Hypotheses under Examination}

Earlier I contrasted the "great U-turn" view with that of "glacial change". What would constitute evidence in support or contradiction of these hypotheses? To begin with, what would represent distributional change sufficient to be "nonglacial"? This is usually considered in terms of statistical significance. For example, Statistics Canada (2002, page 25) suggests, with a sample of some 30,000 households, that a change of 1 percentage point should be considered statistically significant. But what about the economic significance? To get some idea, suppose that the tax and transfer system were approximately linear, as with a uniform tax credit and a constant tax rate. Then, if government spending absorbs 20 percent of tax revenue, a redistributive tax of 5 percentage points would reduce a market Gini of 48 percent by 3 percentage points. ${ }^{5}$ Raising the tax rate from 20 percent to 25 percent would be a major political shift, so this suggests that a change of 3 or more percentage points can certainly be taken as economically significant. In what follows I take such a 3-percentage point yardstick, while recognising that it is essentially arbitrary. The mental experiment does however underline another aspect of the test implicitly being applied: that we are concerned with a sustained change, not with year-to-year transitory variation. A series of Gini coefficients that went from 25 percent to 30 percent and back over the business cycle may exhibit non-glacial behaviour but be essentially trend-free. Evidence in favour of the view that there had been non-glacial change would be that there is a period of a number of years when the level of inequality was 3

\footnotetext{
${ }^{5} \mathrm{~A}$ gross income of $\mathrm{Y}$ becomes a net income of $(1-\mathrm{t}) \mathrm{Y}+\mathrm{A}$, where $\mathrm{A}$ is the value of the tax credit. Since A is the same for everyone (with appropriate equivalisation), the Gini is (1-t) times the value for gross income divided by the mean net income relative to the mean gross income, which is assumed to be 0.8 .
} 
percentage points or more different from a period of a similar number of years in the past.

The existence of a significant rise in recent years does not imply that the U-hypothesis is validated. The change could be a step function. Or the time path could look like that of an aircraft take-off: horizontal for a period and then a steep ascent. In examining the case for the U-hypothesis, I shall be asking whether or not there has been a period of significant decline (again I apply the 3-percentage point criterion) followed by a period of significant increase. This is a different criterion from the more usual practice of fitting a quadratic equation to explain the Gini coefficient $(\mathrm{G})$ as a function of time $(\mathrm{T}): \mathrm{G}=\mathrm{a}-\mathrm{bT}+\mathrm{cT} \mathrm{T}^{2}$. One can then test whether the coefficients on time and time squared are significant (and negative and positive respectively). Such an approach is, in my view, too restrictive. The first reason is that it imposes a particular structure on the U. It does not allow for situations where the decline and rise in inequality are separated by a period of stability: a flat-bottomed U. Most importantly, the quadratic implies that the rise in inequality is continuing. It assumes a $U$ without a serif. In contrast, a $U$ with a serif indicates that the rise has come to an end. Given that we are especially concerned with the recent past, I add a third hypothesis to those being examined: that inequality is continuing to trend upwards in the 1990s (the continuing rise hypothesis).

The second reason why I do not simply fit a quadratic is that, as the diagrams below seek to highlight, we do not have a single consistent series for each country. There are discontinuities that cannot be simply modelled by a dummy variable. There are different series telling different stories. The evidence is of variable quality. These considerations are not readily incorporated into a 
purely econometric analysis. One has to apply judgment as well as statistical packages.

Finally, I should note that the hypotheses are being considered here in relation to the Gini coefficient, which is only one summary measure of the distributional change. Other measures may yield different results. This could go either way. As noted earlier, stability of the Gini coefficient may conceal significant changes in, say, the share of the bottom 20 percent. We may therefore be incorrectly rejecting the hypothesis of non-glacial change. The converse may also be true. A redistribution from the top 10 percent to the next 40 percent may reduce the Gini coefficient significantly, but a test based on the share of the bottom 50 percent would indicate no significant change.

\section{The Pictures}

Figure 1 shows that we can indeed assemble data covering many years, in this case for the US. The data are rich, but they need to be used with care. For instance, while the US Current Population Survey provides data from the 1940s, the earlier form of the official series referred only to "families", leaving out "unrelated individuals" (i.e. people living on their own). Rather than use this partial population, I have selected the "unofficial" estimates of Budd (1970) for the earlier years, together with the OBE synthetic series, drawing on survey information, tax data and the national accounts. In the US, as in other countries, the picture is a patchwork rather than a single seamless garment. Moreover, even what may appear to be a single series often exhibits discontinuities, as there are changes in definitions, in methods of data collection, or in data processing. In assembling the data series I have tried to identify and label the most important 
breaks in the series. One notable break in the CPS series was that in 1993 when the data collection changed from paper and pencil to computer assisted interviewing, and when there was a large increase in the top codes (that for earnings rose from $\$ 299,999$ to $\$ 999,999$ ). This was important, since there was a large rise in recorded inequality in that year, and estimates (Weinberg, 1996, footnote 3) indicate that these changes could account for one half of the recorded increase.

So what support do we find for the various hypotheses? Certainly there has been a rise post-1968. By 1992 the Gini coefficient had risen by some 5percentage points - well in excess of my 3-percentage point yardstick. The nonglacial change hypothesis is accepted. What about the U-hypothesis? Visual inspection indicates an episode of falling inequality from 1961 to 1968, when the Gini fell by $2 \frac{1}{2}$ percentage points. This could be called the first part of the U, but falls short of the 3-percentage point yardstick, and it was preceded by a period that shows virtually no trend. To quote Lindert, "for the US, the shift to more equal pre-fisc incomes lasted only a quarter century, from 1919 to $1953 . .$. Then it stopped altogether" (Lindert, 2000, page 195). (The U might be clearer for the post-fisc distribution.) The Kennedy-Johnson years apart, the US post-war pattern looks more like an aircraft take-off: horizontal for a period and then a steep ascent. The key question concerns when it levels off. Here the break in 1993 makes it difficult to draw firm conclusions about the continuing change hypothesis. The fact that the coefficient in 2001 was 1 percentage point higher than in 1993 (allowing for the new population controls and expanded sample) suggests that cruising altitude may not have been reached, but the next few years will be watched with interest. 
For the UK, we can see from Figure 2 that the picture looks even more like a patchwork. Evidence from household surveys effectively begins in 1961. For the earlier years, we have a synthetic series, based on income tax and other data, that suggests, like the US, little overall change up to the 1960s. Then the pattern departs from that in the US in that there appears to have been a distinct fall of 3 percentage points in the 1970s. The fall was more than reversed in the 1980s. Two features stand out about the UK experience. The first is the sheer magnitude of the rise from 1984 to 1990: the Gini coefficient in the UK rose by more than 1 percentage point a year. The $\mathrm{U}$ is lop-sided to the right. Overall there was an increase in the Gini coefficient of 10 percentage points. Any theory must explain why the UK was twice as severely affected as the US. Even if part of the rise was reversing the fall in the $1970 \mathrm{~s}$, the 1990 figure was 6.7 points higher than the highest value recorded in the 1960s. The second feature is that the 1990s did not show a continuing upward trend. Allowing for the break in the series, the 2000 Gini coefficient is the same as that for 1990. So we have a serif U.

The UK evidence in Figure 2 demonstrates one characteristic of recent changes emphasised by the OECD: that most countries have seen a rise in inequality of market income (income before taxes and transfers). If we are interested in the impact of economic forces such as increased international competition then it is presumably market incomes that interest us most. The same story of rising market income inequality is exhibited by the Canadian data shown in Figure 3: since 1981 the Gini has risen by more than 5 percentage points. But the inequality of disposable income remained unchanged up to 1996. Until that point, the tax and transfer system appears to have been successful in offsetting any exogenous forces making for greater inequality. (I stress "exogenous" since 
market income itself is potentially affected by the existence of taxes and transfers.) What does the Canadian evidence tells us about the U-hypothesis? A supporter may discern a U-shape, but the magnitude of variation is very limited: the range in 30 years is from 35 percent to 37.8 per cent. On this basis, Canada is on the margins of glacial change.

Turning to Scandinavia, we find that Sweden is an example of the problems of data comparability. At face value, there is (Figure 4) a clear Upattern. But as far as the downward movement is concerned, a lot rests on the observation for 1967, of which Gustafsson and Uusitalo say that "because of some differences between the two data sets the comparability is less satisfactory" (1990, page 84). Gustafsson and Johansson (1999) for this reason exclude the 1967 observation from their analysis of changes in inequality over time and the official SCB series starts in 1975. From 1975 to 1981 the fall was smaller but still sufficient ( 3 percentage points) to qualify as non-glacial change. The rise from 1981 to 1990 is 2.8 percentage points, so up to this juncture the $\mathrm{U}$ is muted. In considering the 1990s, there are definitional issues. The official "headline" series, unlike in most other European countries, includes realised capital gains, which leads the series to be much more volatile in the 1990s. This causes differences in the picture depending on the definition chosen. From 1993 to 1999, the rise is 3.7 percentage points if realised capital gains are included, but 1.6 percentage points if they are excluded (Statistics Sweden, 2001, page 3). The judgment reached regarding the continuing rise hypothesis depends therefore on the concept of income employed.

A contrast is often drawn between Norway and Sweden. The picture (Figure 5) in Norway is however far from clear. Indeed those commentating on 
the Norwegian experience have reached different conclusions. According to Bojer, the period 1970-1984 in Norway showed "great stability in the distribution of personal income" (1987, page 257). According to Ringen, the distribution from 1970-1986 "has not been stable" with first a rise and then a fall in inequality (1991, pages 6 and 7). So that, while there has been a clear rise in the 1990s, by 3.3 percentage points from 1990 to 1997 , it is less clear from the existing evidence that this is the second part of a U. On the other hand, Finland (Figure 6) provides much clearer evidence of a $U$, even allowing for the break in the series. The Gini coefficient for disposable income for 1966 was 31.8 in 1966, fell to around 20, and then rose again to 26.6 percent in 2000. The increase from 1993 to 2000 is over 5 percentage points, providing strong support for the continuing rise hypothesis.

In Continental Europe, we find a marked decline from 1959 to 1977 in the Netherlands (Figure 7). As described by van Zanden, "the CBS [Central Bureau of Statistics] figures show quite a marked fall in inequality from 1962 onwards, a fall which continues into the first half of the seventies. About ten years of stability followed, after which a slight increase in inequality can be registered, starting in 1983. ... Thus the long-term fall in income inequality which had run through the $20^{\text {th }}$ century seems to have come to an end half way through the 1980s" (van Zanden, 1998, page 177). The rise from 1983 to 1990 was 3 percentage points, so that the Netherlands just qualifies as a U-shape. It is however a U with a serif, since the 1990s indicate no continuation of the rise: the Gini coefficients for 1990 and 1997 are identical. Moreover, it should be noted that the data for years before 1977 relate to tax units rather than households. In West Germany (Figure 8), the earlier period is surrounded by uncertainty. Both the budget survey (EVS) based 
estimates and the DIW synthetic estimates show falls in the Gini coefficient of more than 3 percentage points, but the timing is quite different. The EVS estimates show a fall from 1962 to 1973 , but this is not mirrored in the DIW synthetic estimates, which show a rise. The preference today is to use household survey data, but it is not evident that we should simply believe one series and not the other. The EVS is based on a quota sample, and a lot of weight attaches to the first observation in reaching the conclusion that inequality fell significantly. The DIW estimates incorporate information from other sources, notably the tax returns. In the more recent period, the EVS and the Panel survey show a similar upward trend, but the overall rise from 1988 to 2001 is less than 3 percentage points. The $\mathrm{U}$ is less than clearcut. The rise over the 1990 s can only be described as "modest" (less than 2 points). Finally, the Italian picture has to be compiled from different series, with different income definitions, reflecting changes in the underlying sources (Figure 9). They certainly suggest significant change, but is not a simple $U$. The time path of the Gini coefficient in its homeland over this period is more like a W. As summarised by Brandolini, "from the early 1970s until $1982 \ldots$ the inequality of household incomes fell dramatically. In the mid1980s, it showed some tendency to grow; a further decline in 1989-91 was soon reversed, and in 1995 the Gini coefficient was back to the value of 1980" (1999, Temi version, page 51). The $\mathrm{W}$ appears to have a serif, since the Gini remained fairly flat from 1993 to 2000 .

\section{Conclusions}

What do I conclude regarding the three hypotheses of non-glacial change, U-shape, and continuing rise? As I have stressed, I do not believe that 
unequivocal answers can be given, as the data at our disposal are a patchwork that requires interpretation. (Moreover, conclusions may have to be revised as new data become available.) The significance of observed changes is a matter for judgment. These qualifications should be borne in mind when considering the summary in Table 1, where bold entries are in accord with the hypothesis, normal type entries do not support the hypothesis, and italic entries are unclear or "on the margin”. Applying the 3 percentage point criterion to the Gini coefficient, there is general support for the view that income inequality has exhibited non-glacial change, with the possible exception of Canada. What about the U-hypothesis? In three of the nine cases, a U-shape can clearly be discerned (UK, Finland and Netherlands), to which we can add the US if the Kennedy-Johnson years are treated as a significant decline, and the more muted cases of Canada and Sweden. The existing evidence in Norway and West Germany is unclear and Italy is more like a W. Where recent rises in inequality have followed earlier episodes of falling inequality, there may be a $U$ or a $U$ : the rise may have levelled off or be continuing. The changes over the 1990s divide into three: 3 countries where the Gini coefficient increased by more than 3 points (Norway, Finland and Italy), 3 countries where there was a modest rise (US, Canada and West Germany), 3 countries where there was no overall change (UK and Netherlands) or different series tell different stories (Sweden).

The principal conclusion that I draw is that there was a wide diversity of experience, even among OECD countries. This means that the explanations must be sufficiently rich to allow a variety of outcomes. 


\section{B Seeking Explanations}

\section{Reduced Demand for Unskilled Workers}

Diversity of outcome is well illustrated by the consensus view about the cause of rising inequality. The textbook explanation is that there has been a shift in demand away from unskilled towards skilled labour, as a result of increased competition from newly industrialising countries (NIC) as a result of globalisation or of technical change biased towards skilled labour, or both these factors operating in conjunction. The reduced demand for less skilled labour means that, with relative supplies of the two kinds of worker fixed in the short-run, in a free labour market there will be a rise in the premium for skilled workers and a decline in the relative wage of unskilled workers. This is taken to be the explanation of rising wage dispersion in the US. In Continental Europe, unemployment benefits and/or minimum wages place a floor and mean that the relative wage of the unskilled cannot fall. According to this view, the demand shift explains the higher unemployment in Europe. There is a unified explanation as to how a single cause has a differential impact on the US and on Continental Europe.

For all its attractions, the standard textbook explanation has important limitations. As the more sophisticated international trade literature has recognised (Davis, 1998), we cannot look at two parallel universes with 2 trading regions (in one case US and NIC, and in the other Europe and NIC). We need a minimum of 3 trading regions (US, NIC and Europe). If in a unified analysis the US and Europe both produce the good that faces NIC competition, then the wage floor in Europe determines the relative goods prices (in a standard two good two-factor Heckscher-Ohlin model, where it is assumed that one good uses unskilled labour relatively intensively). If the minimum wage is unchanged, this prevents the 
relative price from falling. The US is therefore unaffected by increased trade. Europe bears the brunt in terms of unemployment. We have one arm of the "Transatlantic consensus" explanation, but not the other arm. As Neary has noted, the assumption of fixed relative wages in this highly simplified model "imposes an implausible degree of structure on the world economy" (2001, note 3). The result is better stated as a tendency: European unemployment tends to prop up American wages. On this basis, the outcry about globalisation should be in Europe not in the US. On the other hand, Europe may be protected to a degree because it has already become specialised in goods that use skilled labour intensively. If, in the standard trade theory model, we allow the EU to have become specialised, then the consequences of opening trade are different (see Oslington, 1998). Suppose that the NIC is specialised in the other good (which uses unskilled labour intensively). Their entry into world trade drives down its price and hence causes the relative wage of unskilled workers to fall in the US, which produces both goods. We then have the US side of the textbook conclusion, but not the European side, since the demand for the good using skilled labour intensively is higher, causing a fall in unemployment. Either way, one or other part of the "textbook" view cannot apply.

The trade explanation is not therefore a simple application of standard theory of the Heckscher-Ohlin variety. The model has to be expanded. Nor is this the only limitation. Here I consider two further aspects that apply when considering both trade and technology versions of the demand shift theory: (a) supply side reactions and alternative theories of pay determination, and (b) the relation between factor prices and personal incomes. 


\section{The Supply Side}

Suppose that we now consider the relation between the skill premium and the supply of skilled labour. In the simplest form of human capital theory, acquisition of a skill requires $\mathrm{S}$ years of training, during which the person is paid nothing, so that the earnings career is postponed by S years. To provide the same present value of earnings over a fixed working life, the earnings of skilled workers have to be higher by a factor $\mathrm{e}^{\mathrm{rS}}$ where $\mathrm{r}$ is the real interest rate. If there are no barriers to acquiring skills, then this factor determines the long-run equilibrium wage differential. It should be noted that the existence of this differential does not imply inequality: it is a compensating differential equalising net advantage. If the labour market were initially in equilibrium, then a rise in the skill premium, caused by increased relative demand for skilled workers, will induce an increase in the supply of skilled workers. A rise in the premium for college educated workers means that more people choose to stay on at college.

At this point we should note that we are assuming away barriers to entry into skilled employment. One such barrier is the capital market. People may not be able to borrow to finance their education, and their parents may lack the necessary capital. Families may be trapped in a low level equilibrium (Atkinson, 1997). This process may have been exacerbated by the fact that real interest rates are now higher than they were in the 1970s (when they were negative). Borrowing has become more costly. To the extent that this is the case, we have arrived at a quite different explanation of increased earnings dispersion: that there has been an increase in the factor $\mathrm{e}^{\mathrm{rS}}$. The explanation is to be found not in the labour market, on which economists tend to focus, but in the capital market. 
Even where the barriers can be overcome, the acquisition of human capital takes time. The stock of college-educated labour cannot adjust at once. But in the case of the US, we are talking about a rise in earnings dispersion that began more than a generation ago. Surely by now the supply would be increased? To quote James Galbraith, "nearly thirty years since the start of rising inequality, many millions have acquired the skills appropriate to the age. Word-processing, accounting and calculating on spreadsheets, e-mail and the Internet, computer graphics and publication, computer-aided design: none of this is any longer esoteric. Yet the readjustment of incomes to a wider and more equal distribution of skill levels hasn't even begun to happen" (1998, pages 7 and 8). Absence of adjustment may be due to the nature of the "skills" that are rewarded in the labour market. "Increasing economic value now attaches to individual attributes of a kind less likely to be achieved through the educational system than ascribed through processes of socialisation within generally more advantaged families and communities" (Erikson and Goldthorpe, 2002, page 40). In his analysis of telephone operators, Bresnahan concluded that: "workers need more people skills, and less cognitive ones" (1999, page F405). It may therefore be that, in seeking an explanation, we are focusing on the wrong kinds of skills.

Alternatively, labour markets may function differently. In his account of a period of narrowing wage differentials, Reder states that "the long-run decline in the skill margin in advanced countries has not occurred slowly and steadily. Instead, the skill margin appears to have remained constant for relatively long periods of time and then to have declined sharply within a very few years" (1962, p.408). Institutional labour economists have typically assumed that supply and demand only place limits on the possible wage differentials, with other factors such 
as bargaining or social convention determining where between these limits wages actually lie. Social conventions may play an instrumental role in removing the indeterminacy. Social codes may however enter more directly into economic behaviour. Akerlof (1980) describes a model where individual utility depends not only on income but also on reputation that is based on conformity with the social code. The loss of reputation if one departs from the social code depends on the proportion who believe in the code, which is undermined if people cease to observe it.

Such a reputational approach is applied in Atkinson (1999) to the relation between wages and productivity. Suppose that there is a social code, or pay norm, that limits the extent to which individual earnings increase with earnings potential. Where this code is followed, people are paid a fraction (less than unity) of their productivity plus a uniform amount. Such a policy involves a degree of redistribution and low productivity workers can be expected to subscribe to the pay norm. But other workers will also accept it, even where they could be paid more if they broke the norm, since - if they believe in the norm - by breaking it they would suffer a loss of reputation. The extent of the loss rises with the proportion of the population who at that time believe in the norm. Employers are also concerned with their reputations. When they create a job, it is determined in advance whether or not it is paid according to the pay norm. The profitability of the job depends not only on the pay but also on the acceptance of the job by the worker with which it is matched. Matching is assumed to follow a random process, but is only successful where employer and worker either both observe the code or both do not. Employers determine their pay policy (i.e. whether or not to observe the social code) on the basis of comparing expected profitability, which depends on the proportion, and 
characteristics, of workers who accept different pay offers. The expected profitability of breaking the social code has to exceed the cost of the consequential loss of reputation, which is assumed to vary across employers, so that some employers may observe the code while others depart from it. There will therefore be a proportion of jobs which accord with the pay norm. If the proportion of the population who believe in the pay norm is less (greater) than this, then the extent of belief is assumed to grow (fall).

There is therefore a dynamic process of adjustment. As Akerlof has shown, the process is likely to be of the "tipping" kind identified by Schelling (1978). Depending on the initial conditions, a society converges to a high level of conformity with the social code, or to the virtual absence of conformity. In this kind of situation, an exogenous shock may switch the society from an equilibrium with conformity to the pay norm, and hence relatively low wage differentials, to an equilibrium where everyone is paid on the basis of their productivity. Such an exogenous shock may have been a fall in the weight attached by employers to reputation. Or, reflecting again changes in the capital market, it may be that greater weight is attached to short-run profits. We may therefore observe a discrete change in the wage distribution, an episode of increasing dispersion, which is not reversed when the original cause is removed. In this way we have arrived at a more textured explanation of rising wage dispersion, with rather different implications from the textbook supply and demand account. It can, for example, explain why the same shock may have different effects on different countries, depending on the extent of differences in underlying productivity. 


\section{From Factor Prices to Personal Incomes}

The conventional explanation begins and ends with the relative wages of skilled and unskilled workers. However there are several steps between relative factor prices - the central focus of economics textbooks - and the distribution of disposable income among households, which is what we have been examining in the empirical section. These steps are typically ignored, but are potentially important.

Suppose that a man loses his job as an unskilled steelworker, as a result of competition from imports, and has to take a lower paid job in the retail sector. The impact on the household disposable income cannot be predicted solely from this information, nor can we place him in the distribution without knowing about:

- $\quad$ His other sources of income;

- The income of other members of the household;

- $\quad$ The size and composition of the household in which he lives;

- $\quad$ The consequential changes in taxes and transfers.

Working from the bottom, we can see that the net of tax change in income is reduced by the existence of progressive taxation. At an overall scale, with a marginal tax rate of 30 percent, a linear tax system means that a 5 percentage point rise in the Gini coefficient for market incomes translates into a $3 \frac{1}{2}$ percentage point rise in the Gini for disposable income. On this basis, we would expect to find differences across countries in the impact on disposable income of a given shock to market income according to the degree of progression of their tax systems.

This might lead us to expect a larger rise in inequality of disposable income in the US and the UK, where tax systems are less progressive. But we 
have also to remember that these countries have in-work benefits that generate high implicit marginal rates of tax (and mean that the tax system is not linear): the Earned Income Tax Credit in the US and the Working Families Tax Credit in the UK. These benefits are tapered with income, and - for much of the relevant range - increase the marginal tax rate. The worker facing a pay cut would find in the UK that his tax credit rises to offset part of the fall in gross earnings. The implicit marginal tax rate can be 70 percent or higher. Tax benefit policy therefore considerably moderates the impact of increased wage dispersion.

Equally, we have implicitly been assuming that the low skilled worker is at the bottom of the distribution. But his or her ranking depends on the income of the other members of the household and on the size and composition of the household. It is a very different situation if he is the sole earner in a household with 4 children from that where he is a single man. Moreover, we cannot assume that all male unskilled workers are married to unskilled workers. If, at the other extreme, every unskilled worker is married to a skilled worker (and there are equal numbers, all married), then a change in the skill premium does not affect the household distribution of income. There will be a change in the distribution within the household, and this may well be important, but it is not captured in the usual statistics.

Lastly, there are other sources of market income besides earnings, notably capital income. He may be like the soldiers who, in Tawney's phrase, went off to the First World War carrying the sum total of their possessions. But today it seems more likely that he has significant assets, both real property and financial assets, and liabilities. The liabilities may exceed the assets for some people, but the household sector as a whole has substantially positive net worth. Capital 
income is not limited to a minority capitalist class. It is therefore surprising that capital is entirely missing from the textbook account of rising inequality. The production function should surely include capital as well as skilled and unskilled labour? Globalisation, and other forces influencing the skill premium, is likely to have affected the rate of return to capital. The search for shareholder value may have meant that the steelworker's job disappeared, but the higher capital income may be funding his early retirement.

For these reasons, a rise in inequality of individual gross earnings may be considerably moderated when we follow through the implications for the distribution of household equivalised disposable income.

\section{Top Incomes}

The textbook story concerns the plight of the unskilled worker in a globalising world of rapid technological change. It tells us less about the impact of these forces on upper income groups. In the same way, the Gini coefficient is a convenient summary indicator, but may not be a good guide to what is happening at the top of the distribution. If we focus just on the shares of top income groups, then we can make use of longer-run data derived from income tax returns. Tax data have many shortcomings. They relate to gross (pre-tax) income. They are affected by tax evasion and avoidance. The definitions of income and the income unit follow those of the income tax legislation, which varies both over time and across countries. Capital income is recorded to differing degrees in different countries, and the same applies to executive compensation in kind and in stock options. Income tax data do however have the merits of covering the whole second half of the twentieth century and of providing considerable detail on the 
top of the distribution. Figures 10 and 11 show the results of studies for four OECD countries. To the US, UK and Canada, I now add France, as it was the research of Piketty (2001) for France that revived use of this source - which had of course been extensively used half a century ago by Kuznets (1953) for the US. In order to relate the tax data to the whole population, we need reference totals for the number of tax units and total income, in order to calculate the share in total income of the top x percent of total tax units. The total of tax units is relatively easy to approximate from population statistics, but the studies cited have adopted different approaches to the income totals, particularly with regard to the inclusion or exclusion of transfer incomes. In view of this, I have concentrated here on the distribution within the top income groups: the share of the top 1 percent in the total income of the top 10 percent (Figure 10) and the share of the top 0.1 percent in the total income of the top 1 percent (Figure 11). This is in itself of considerable interest. In presenting income distribution data in terms of decile shares, we often overlook the fact that income within the top 10 percent is highly unequally distributed. In the same way, the top 1 percent cannot be regarded as a homogenous class. Pen (1971, page 9) comments on the widespread tendency to overstate the number of the very rich. People tend to assume that most members of the top 1 percent are CEOs or pop singers or footballers.

Figures 10 and 11 demonstrate the inequality within the top income groups. If one takes the UK income distribution in 1979 (a year of relatively low inequality), then according to the income tax data (the UK is shown by squares in Figures 10 and 11) the share of the top 10 percent in gross income was 25.3 percent: i.e. $2^{1 / 2}$ times their proportionate share. Within the top 10 per cent, the top 10 percent (i.e. the overall top 1 percent) had a share of 20.9 percent of the 
total income of the decile group: i.e. twice their proportionate share. And the top 10 percent within the top 1 percent (the overall top 0.1 percent) had a share of 22 percent of the total income of the percentile group. The similarity of these numbers reflects the fact that the upper tail of the distribution has approximately a Pareto form, and in this sense they are not surprising. They serve nevertheless to highlight the way in which - at whatever point one slices the upper reaches of the distribution - the remaining section is characterised by a similar degree of relative inequality. Assuming that the cumulative distribution $\mathrm{F}$ within the top group is such that (1-F) is proportional to $\mathrm{y}^{-\alpha}$, where $\mathrm{y}$ is income, then the within-group share of the top 1 percent within the top 10 percent, denoted by $S_{1} / S_{10}$ is $(0.1)^{(1-}$ ${ }^{1 / \alpha)}$, which falls with the Pareto exponent, $\alpha$. This method of estimating the Pareto coefficient was proposed by Macgregor (1936), who noted that it made a bridge between Pareto and Lorenz. For this reason, to draw a distinction from other methods of estimating the Pareto coefficient, I refer to it as the Pareto-Lorenz coefficient.

Looking across the four countries, we see two striking features of the post war period in Figures 10 and 11. (The US data are shown by circles; the Canadian data by diamonds; and the French data by a solid line.) The first is the similarity in the downward trend in the relative shares for the first twenty-five years. The implied Pareto exponents were already quite similar, but they rose. In 1949 the Pareto-Lorenz coefficients derived from Figure 10 are 2.24 in Canada and France, 1.96 in the US and 1.81 in the UK. By 1970 the Pareto-Lorenz coefficients had risen to 2.50 in France, 2.54 in the US, 2.57 in the UK and 2.67 in Canada. For the shares of the top 0.1 percent within the top 1 percent (Figure 11), the series were already close and the relative shares fell together. 
The second striking feature is that the latter part of the century saw a sharp rise in the relative shares and fall in the Pareto-Lorenz coefficient in the AngloSaxon countries, but not in France. We have a much clearer $U$ shape, without apparent serifs. By 1998, the implied Pareto-Lorenz coefficients from Figure 10 had fallen to 2.10 in Canada, 1.95 in the UK and 1.83 in the US. The US and the UK had switched position, but the values are essentially the same as in 1949. It is true that the bottom of the $U$ came later in the UK and Canada (around 1978), and that we have to allow for a break in comparability in the UK series with the introduction of independent taxation in 1990, but the overall time-path in the three Anglo-Saxon countries is similar. In contrast, as pointed out by Piketty (2001), France did not see a sharp upward movement in inequality. Compared with 1970, the French Pareto-Lorenz coefficient in 1998 is fractionally down (Figure 11) or actually higher (Figure 10).

\section{Possible Explanations of Top Income Inequality}

The evidence just presented for the top of the distribution provides clear support, in three Anglo-Saxon countries, for the $U$ hypothesis and for the continuing rise hypothesis. The upward arm of the $U$ may be explained by the same forces of globalisation and technology. According to the "superstar" theory of Rosen (1981), the expansion of scale associated with globalisation and with increased communication opportunities has raised the rents of those with the very highest abilities. Where the second-best performer's market share is limited by the "reach" of the top performer, and this reach is extended by technical changes such as those in ICT, and by the removal of trade barriers, then the earnings gradient becomes steeper. The explanations for earnings inequality at the top may however 
be different; we may have to consider capital income rather then earned income. We have to cast the net wider if we are seeking to explain the evolution of top income shares.

Here I confine myself to noting that the empirical representation in terms of the Pareto exponent provides a direct link to a number of theories advanced in the past (and largely ignored today). If the upper tail can be approximated by the Pareto distribution, then the share of the top 0.1 percent within the top 1 percent is a linear function of $(1 / \alpha)$ :

$$
\log \left[\mathrm{S}_{1} / \mathrm{S}_{10}\right] \quad=\mathrm{b}(1 / \alpha-1)
$$

In the case of earnings, one set of theories that lead directly to predictions concerning the Pareto exponent are those dealing with executive remuneration in a hierarchical structure. The model advanced by Simon (1957) and Lydall (1959 and 1968, page 129) leads to an approximately Pareto tail to the earnings distribution, where $1 / \alpha=\log _{\mathrm{e}}[1+$ increment with promotion $]$ divided by $\log _{\mathrm{e}}[\mathrm{span}$ of managerial control]. As noted by Phelps Brown (1977, page 309), plausible values for the span and increment imply values of $\alpha$ higher than observed in the actual distribution. On the other hand, the theory suggests one approach to understanding the variation in $\alpha$ : that the size of the increment for promotion fell over the first half of the post war period and then rose, except in France.

The differing experience across countries in the second period could be explained by applying a "tipping" model similar to that described above. Those at the top of a "flat" hierarchy may, conforming with the pay norm, accept lower pay than they could secure in a firm with a "steep" hierarchy (with generous stock options). Their adherence may however be a function of the extent of compliance in the economy as a whole, both because this affects the potential loss of 
reputation from breaking the code and because it affects the chance of being better paid if they entered the market for another job. The existence of executive remuneration surveys provides in this case a powerful instrument for assessing the degree of conformity, as does the presence of external directors on remuneration committees. In this situation, an interior equilibrium may be unstable, with the economy tending to one extreme or the other. With a flat hierarchy, the pay increments are the reservation wage; with a steep hierarchy they are constrained by what shareholders tolerate. What we have observed in the US, UK and Canada may have been a progressive move from one equilibrium to another. It is possible for example that a reduction in firm time horizons in some countries has led to such a shift.

What can explain the first part of the period, when $\alpha$ was rising? Here we have to recognise that earnings are only part of the income of the top groups. As Piketty (2001) has demonstrated for France, the composition of income changes radically within the top 10 percent. For those in the "first" 5 percent, earnings (in 1998 in France) accounted for 90 percent of their income; for those in the top 0.01 percent, capital income accounted for over 60 percent of total income. This brings us to theories concerned with the accumulation of capital. Meade (1964) developed a model of individual wealth holding, allowing for accumulation and transmission of wealth via inheritance, and this model has been analysed in a general equilibrium setting by Stiglitz (1969). With equal division of estates at death, a linear savings process, and persistent differences in earnings, in the longrun the distribution of wealth mirrors the distribution of earnings (Atkinson and Harrison, 1978, page 211). In contrast, alternative assumptions about bequests can generate long-run equilibria where there is inequality of wealth even where 
earnings are equal. Stiglitz shows how the operation of primogeniture in passing on wealth can lead to a stable distribution with a Pareto upper tail, with

$$
1 / \alpha=\log _{\mathrm{e}}[1+\operatorname{sr}(1-\mathrm{t})] / \log _{\mathrm{e}}[1+\mathrm{n}]
$$

where $\operatorname{sr}(1-t)$ is the rate of accumulation out of wealth, $r$ being the rate of return and $\mathrm{t}$ the tax rate, and $\mathrm{n}$ is the rate of population growth (Atkinson and Harrison, 1978, page 213). For stability (and $\alpha$ greater than 1), the overall population growth rate has to exceed the rate of accumulation by the wealthy. The model is highly stylised but again provides a direct explanation for the decline and then rise of the top shares over the post war period. In the first post war decades, the net rate of return was increasingly reduced by progressive taxation and by inflation; the 1980s and 1990s then saw a recovery of the real rate of return and in the Anglo-Saxon countries (although to varying degrees) - reductions in top income tax rates. These models treat wealth accumulation as deterministic. Champernowne $(1936,1973)$ set out a rich theory of the evolution of incomes subject to stochastic shocks. This has been developed by Vaughan (1978, see also 1979), who shows that the Pareto exponent is a function of the degree of volatility. This provides a second element that can contribute to the explanation of the $U$ shape of top income shares, if volatility first fell over the post war period, as the Golden Age became established, and then increased in the more turbulent later years of the century.

These models indicate some promising routes to the specification of econometric equations linking the share of the top 1 percent within the top 10 percent (and the share of the top 0.1 percent within the top 1 percent) to macroeconomic and other variables, but they need to be developed further. Given the 
significant changes at the top of the distribution, we need to look more widely when seeking explanations.

\section{Prospects for the Future}

Those drawing attention to rising income inequality are right to be concerned about the future. With the possible exception of Canada, there has been significant change in the distribution of income in all nine OECD countries examined here. In some countries, such as the UK, the increase in recorded inequality is considerably larger than the rise in the US that has attracted so much attention. At the same time, these recent changes should not be extrapolated into an inexorable rise in inequality in the future. There are at least three reasons for not drawing such a conclusion. First, the empirical evidence suggests that in some countries the rise does not appear to be continuing: we have a $U$ rather than a sans serif $U$. Secondly, the distribution of income is a highly complex phenomenon, and it would be surprising if a single explanation sufficed for all countries and all periods. Globalisation and ICT may together have reduced the job opportunities of those with low levels of skill, but there are also other forces in operation and these forces may change direction. For example, I have suggested that part of the explanation of greater inequality, especially at the top of the distribution, is the rise in the net rate of return to capital. If the rise is unwound in the next decade, with investors enjoying lower yields than in the 1980s and 1990s, we may expect the increased inequality to be reversed. Thirdly, we must not lose sight of the role of policy. I have concentrated on the explanation of variations in inequality of market income, but changes in tax and social transfer policy have played a major role in increasing inequality in a number of countries. 
Table 1 Summary of Empirical Evidence on Gini Coefficient

\begin{tabular}{|c|c|c|c|}
\hline Country & Non-Glacial Change? & U-Turn? & Continuing Rise? \\
\hline United States & $\begin{array}{l}\text { Significant change: } \\
\text { Gini in } 1992 \text { higher by } 5 \\
\text { points than in } 1968 .\end{array}$ & $\begin{array}{l}\text { Not clear in postwar } \\
\text { period. Yes, if treat } \\
\text { Kennedy-Johnson years } \\
\text { as significant decline. }\end{array}$ & $\begin{array}{l}\text { Modest rise from } 1993 \\
\text { to } 2001 .\end{array}$ \\
\hline $\begin{array}{l}\text { United } \\
\text { Kingdom }\end{array}$ & $\begin{array}{l}\text { Significant change: } \\
\text { Gini in } 1990 \text { higher by } 10 \\
\text { points than in } 1978 \text {. }\end{array}$ & Yes, U. & $\begin{array}{l}\text { No overall change in } \\
\text { Gini } 1990 \text { to } 2000 .\end{array}$ \\
\hline Canada & On the margin. & Muted. & $\begin{array}{l}\text { Modest rise in } \\
\text { Gini from } 1990 \text { to } \\
1999 .\end{array}$ \\
\hline Sweden & Significant change. & Muted up to 1990. & $\begin{array}{l}\text { Different pictures from } \\
\text { different series. }\end{array}$ \\
\hline Norway & Significant rise in $1990 s$. & Picture unclear. & $\begin{array}{l}3 \text { point rise from } 1990 \\
\text { to } 1997 .\end{array}$ \\
\hline Finland & Significant fall and rise. & Yes, U. & $\begin{array}{l}5 \text { point rise } 1993 \text { to } \\
2000 .\end{array}$ \\
\hline Netherlands & Significant change. & Yes, U. & $\begin{array}{l}\text { No overall change in } \\
\text { Gini 1990-1997. }\end{array}$ \\
\hline West Germany & $\begin{array}{l}\text { Significant change: } 1973 \\
4.4 \text { points lower than } \\
1962 \text {. }\end{array}$ & Picture unclear. & $\begin{array}{l}\text { Modest rise } 1990 \text { to } \\
2001 .\end{array}$ \\
\hline Italy & Significant falls and rises. & More like $W$. & $\begin{array}{l}\text { Sharp rise 1990-1993, } \\
\text { stable } 1993-2000 .\end{array}$ \\
\hline
\end{tabular}


Appendix

Figure 1 US Income Inequality 1945-2000

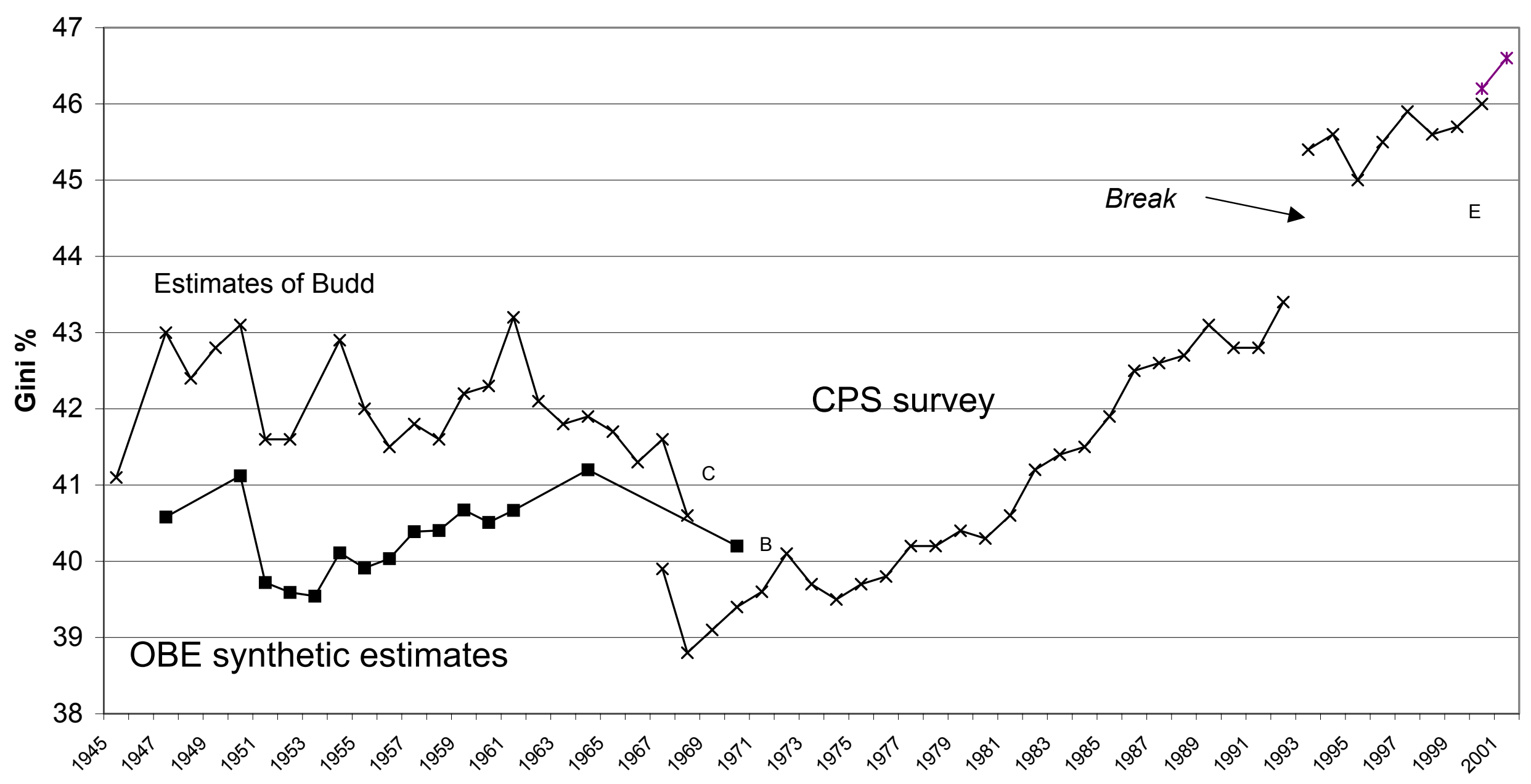


Figure 2 UK Income Inequality 1949-2000

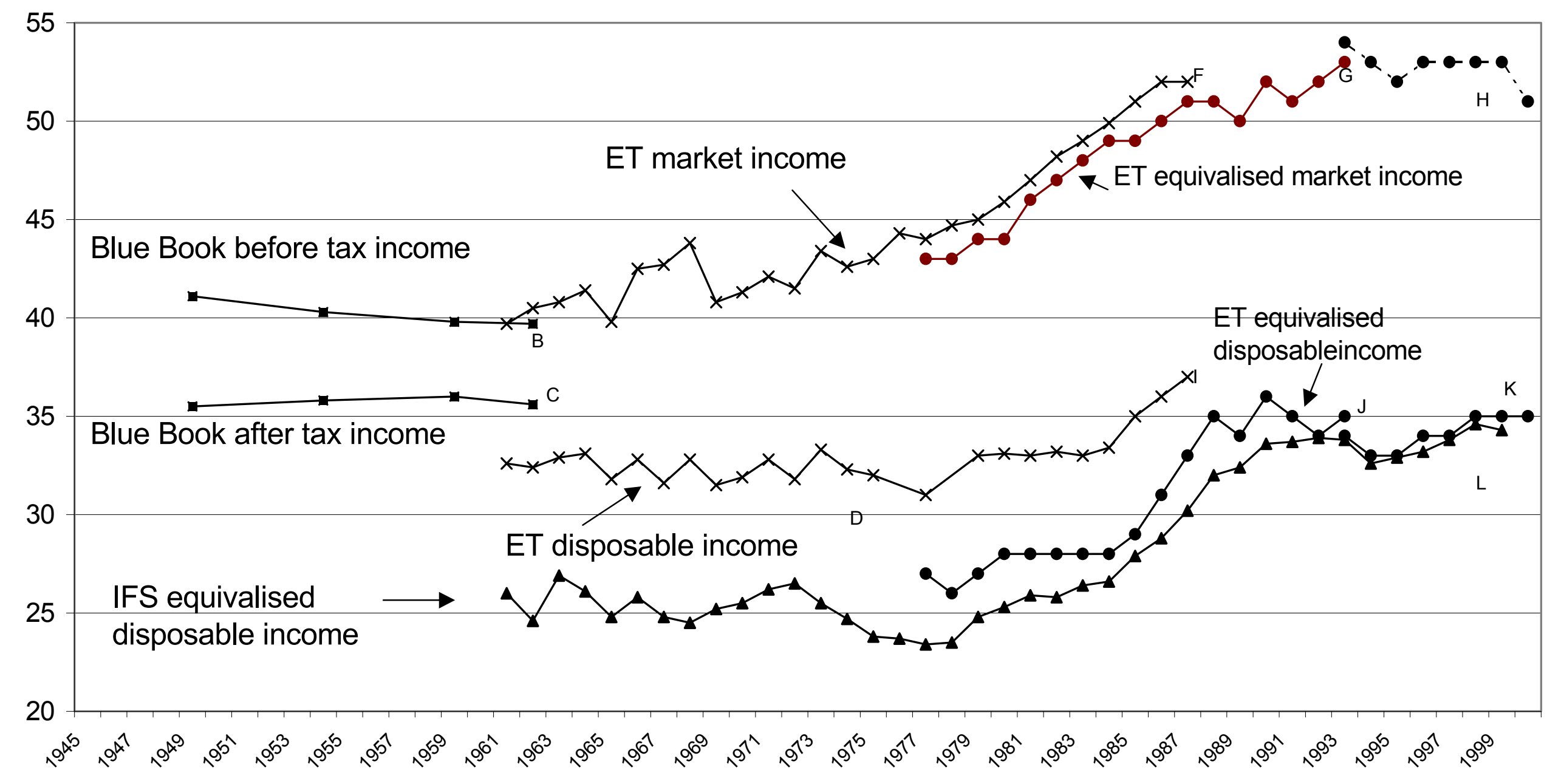


Figure 3 Canada Income Inequality 1965-1999

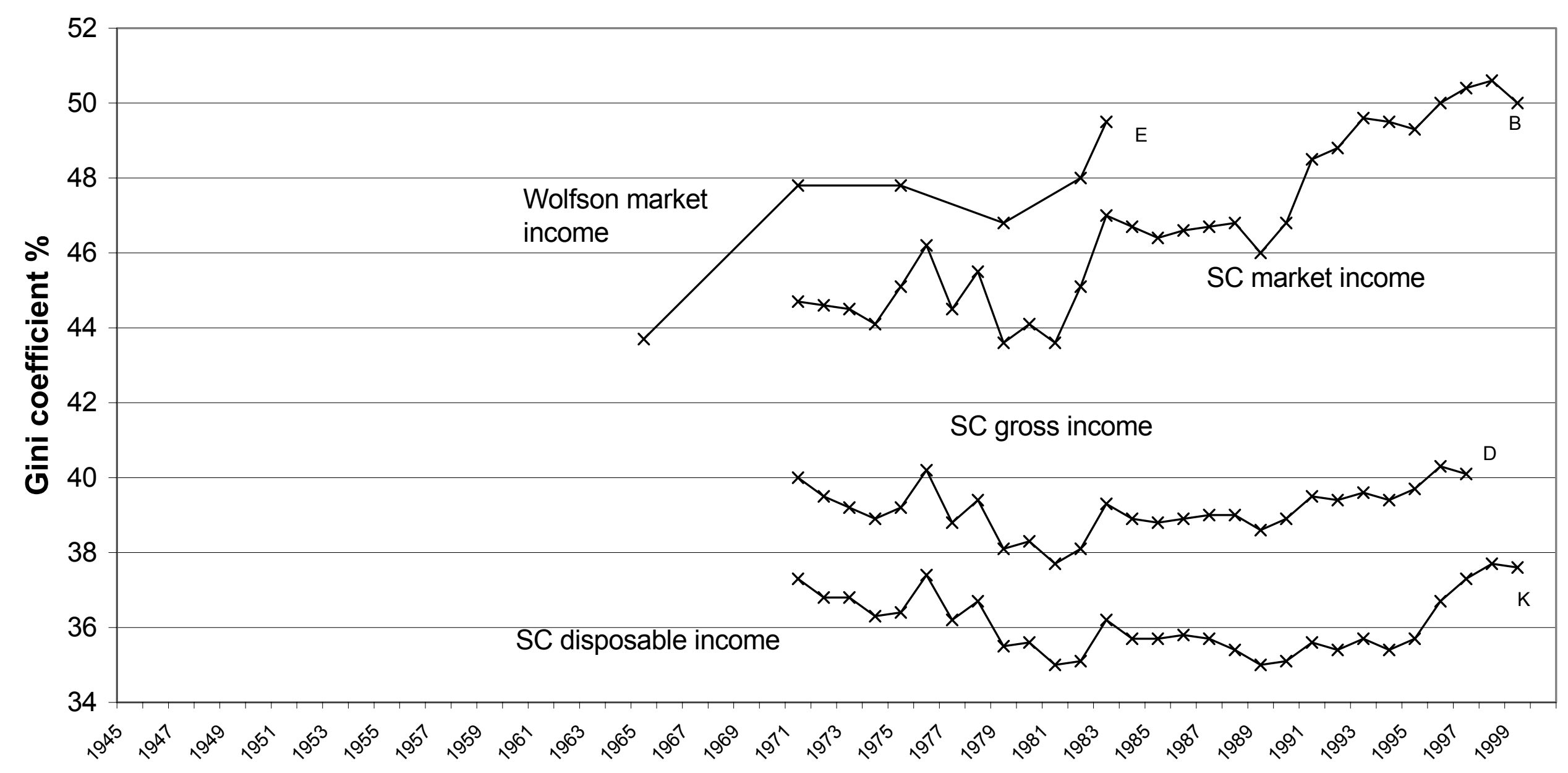


Figure 4 Sweden Income Inequality 1967-1997

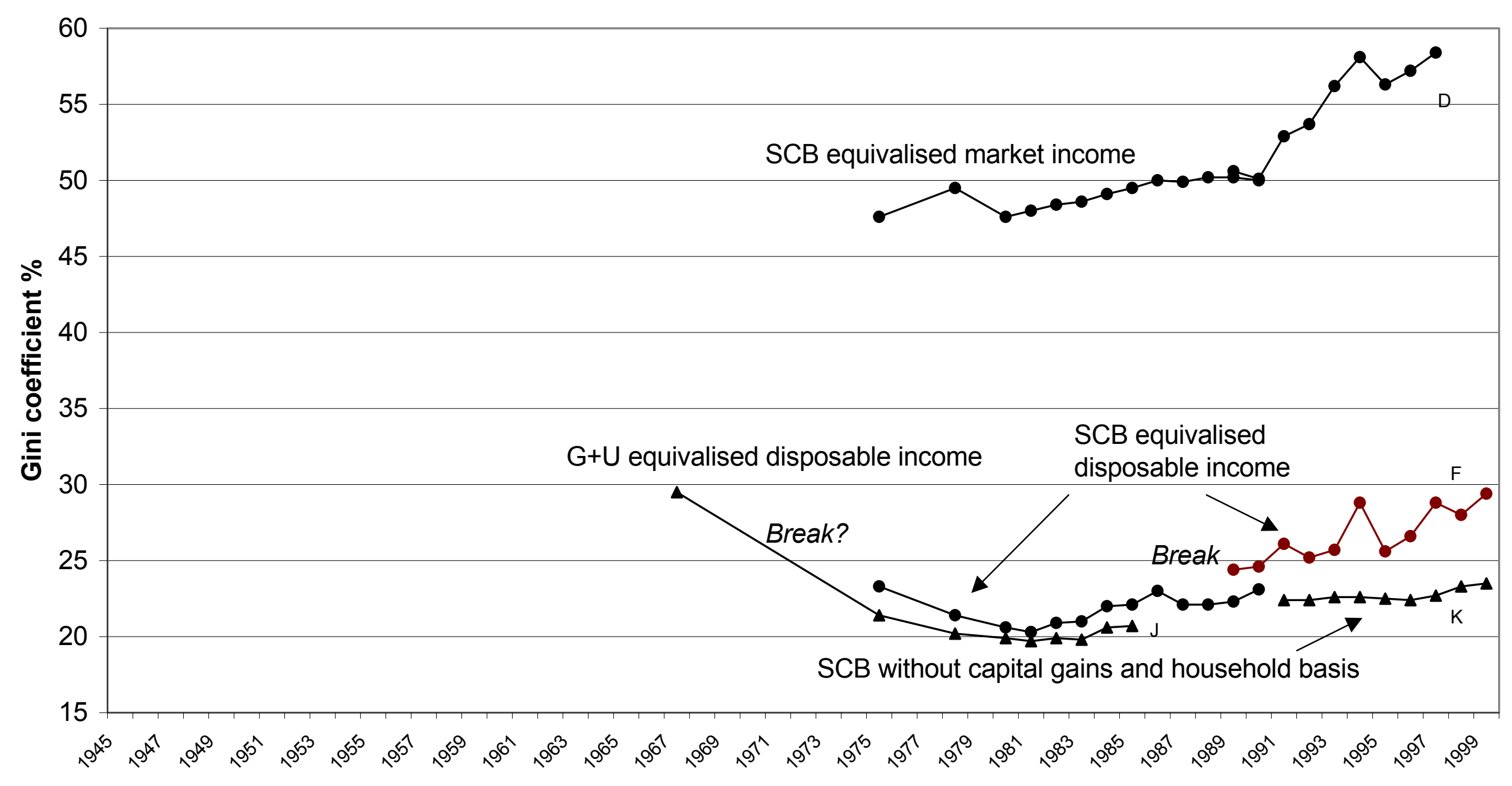


Figure 5 Norway Income Inequality 1970-1997

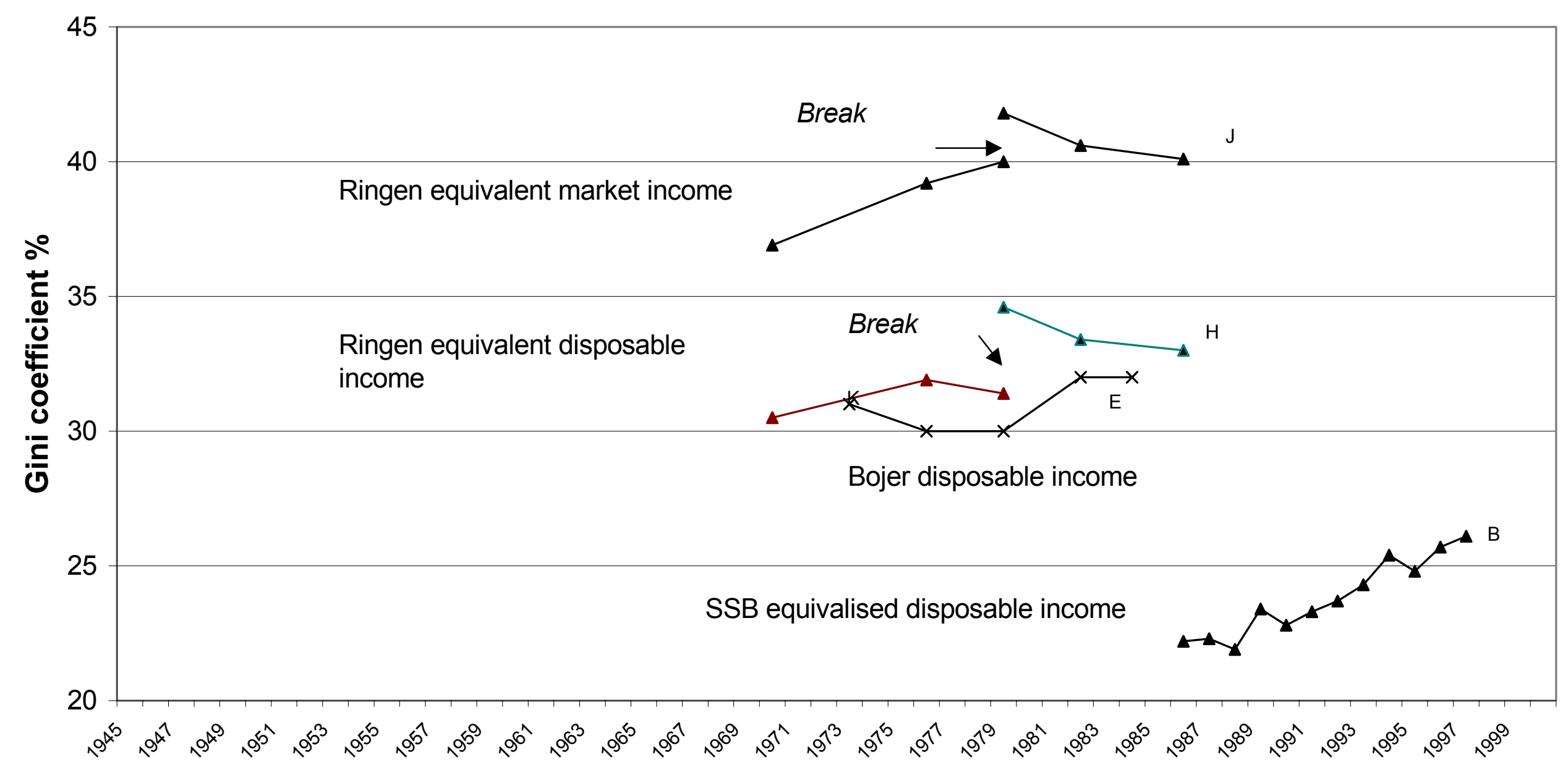


Figure 6 Finland Income Inequality 1966-2000

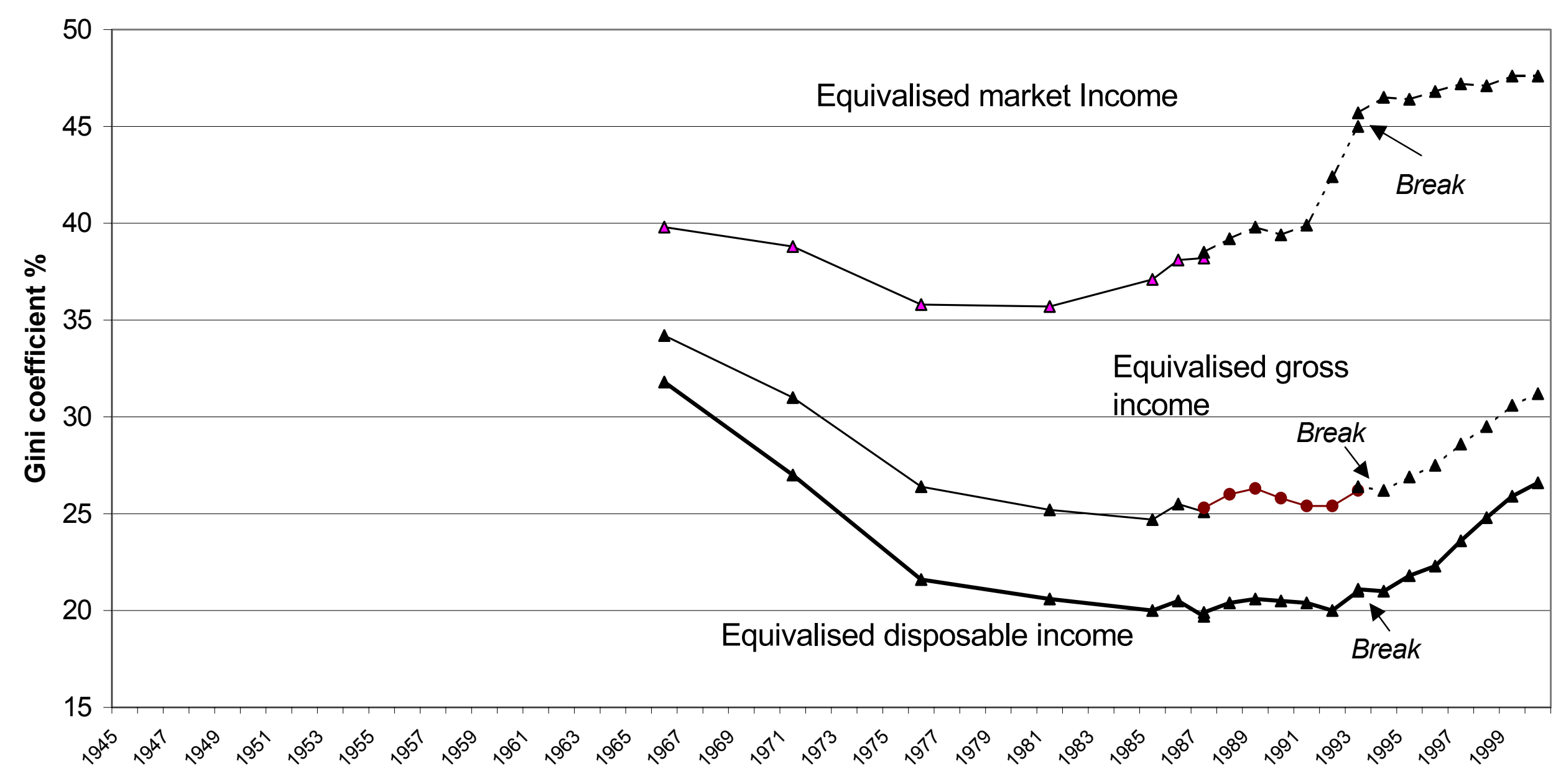


Figure 7 Netherlands Income Inequality 1947-1997

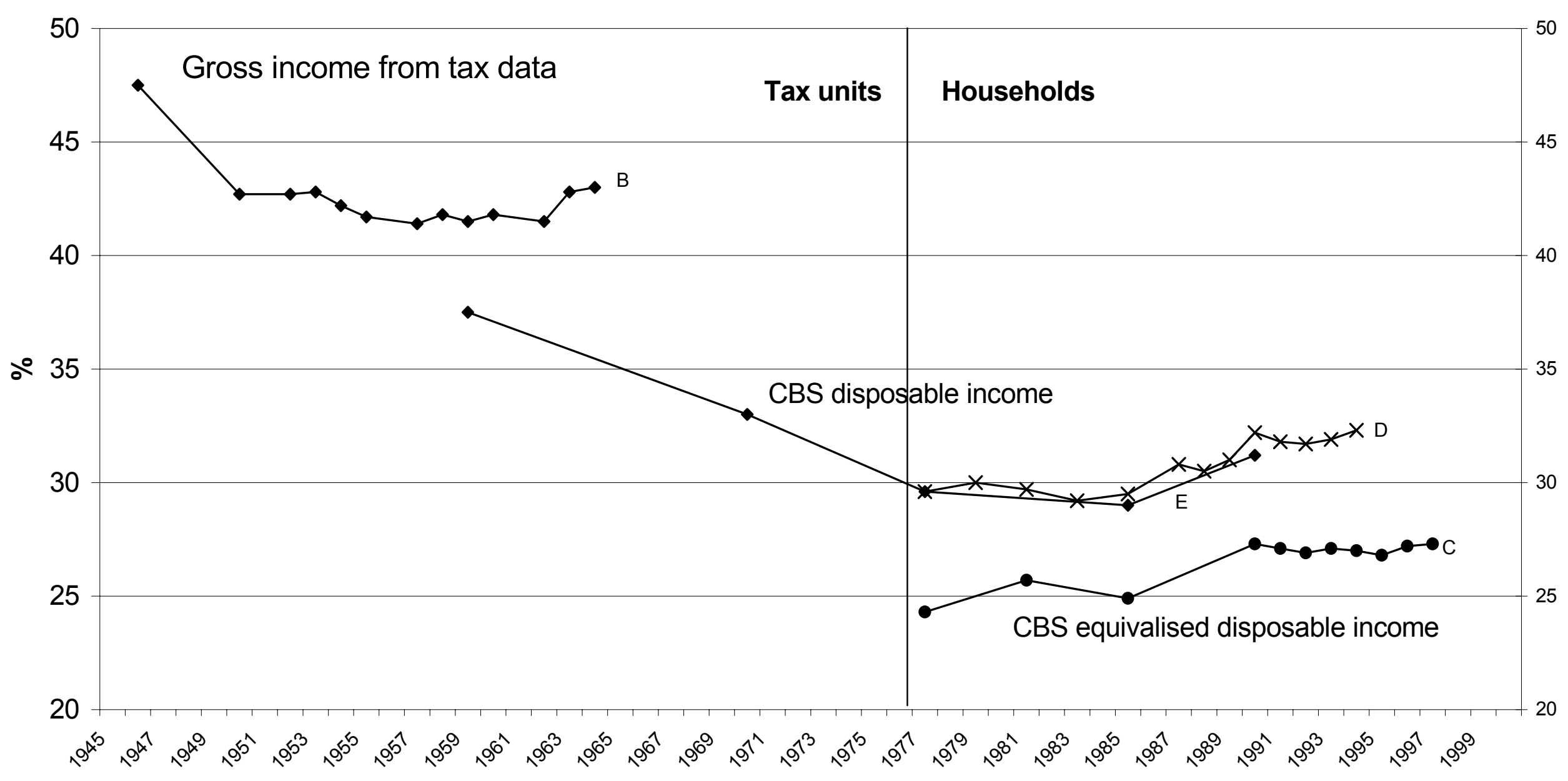


Figure 8 West Germany Income Inequality 1950-2001

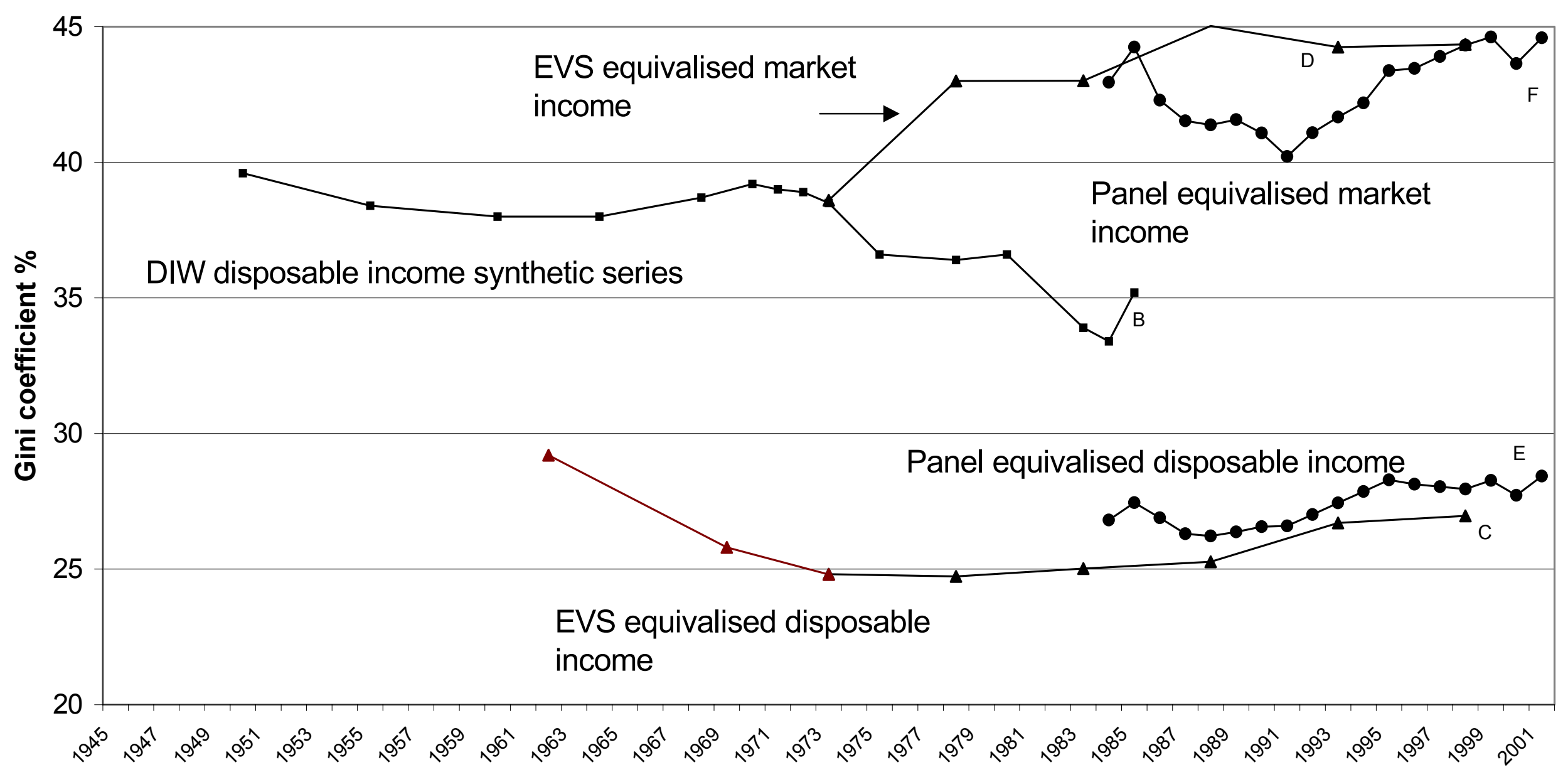


Figure 9 Italy Income Inequality 1968-2000

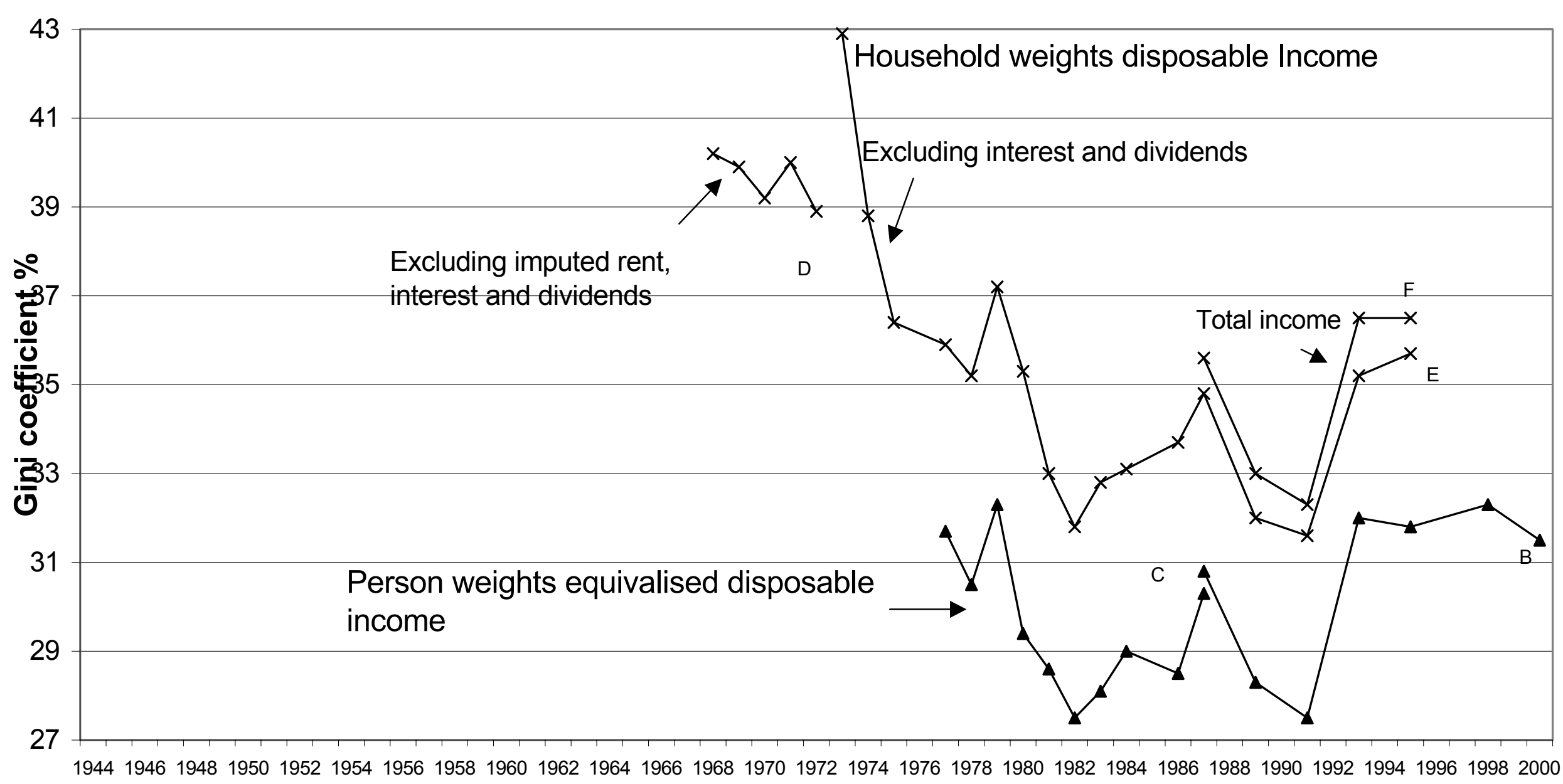




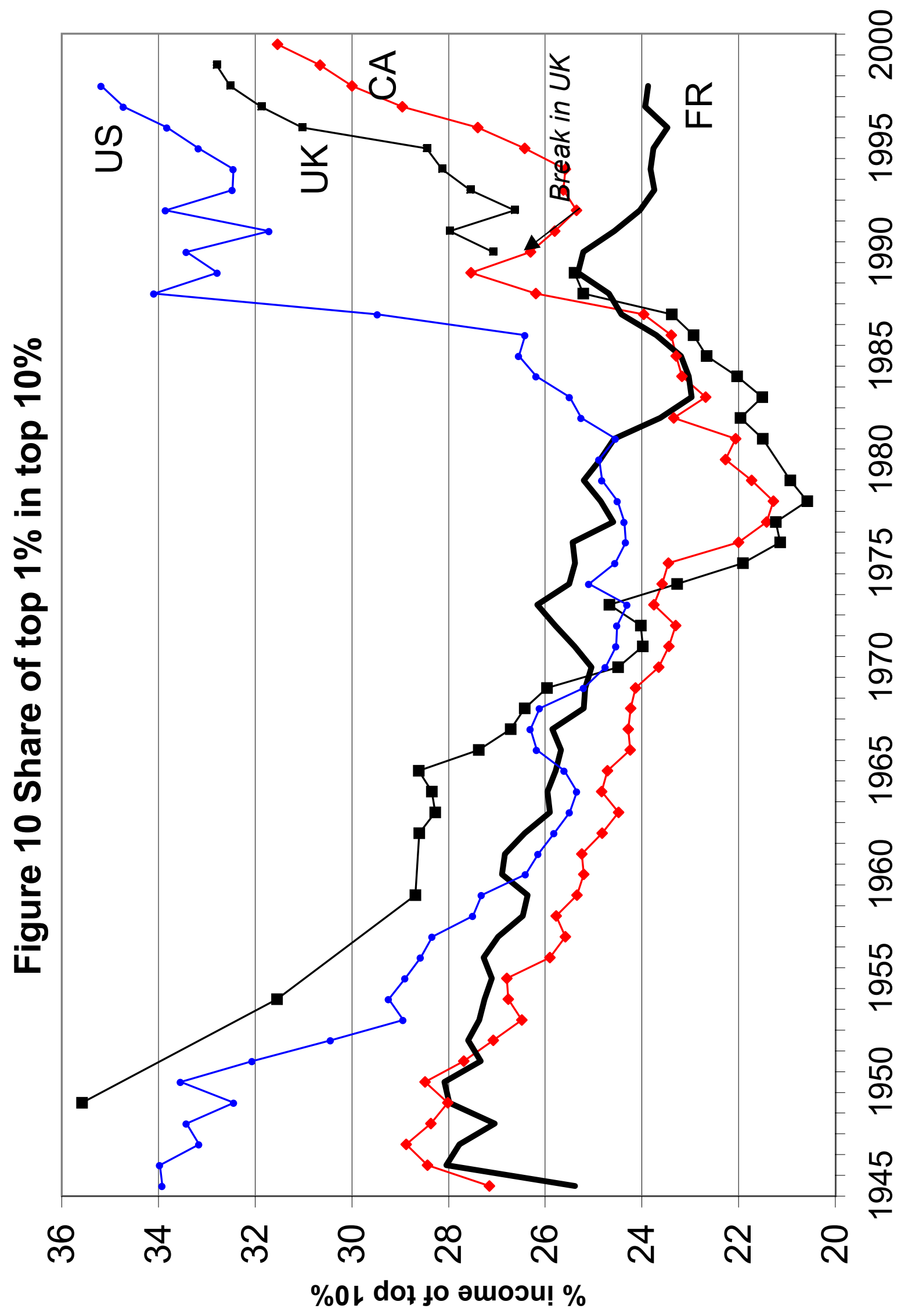




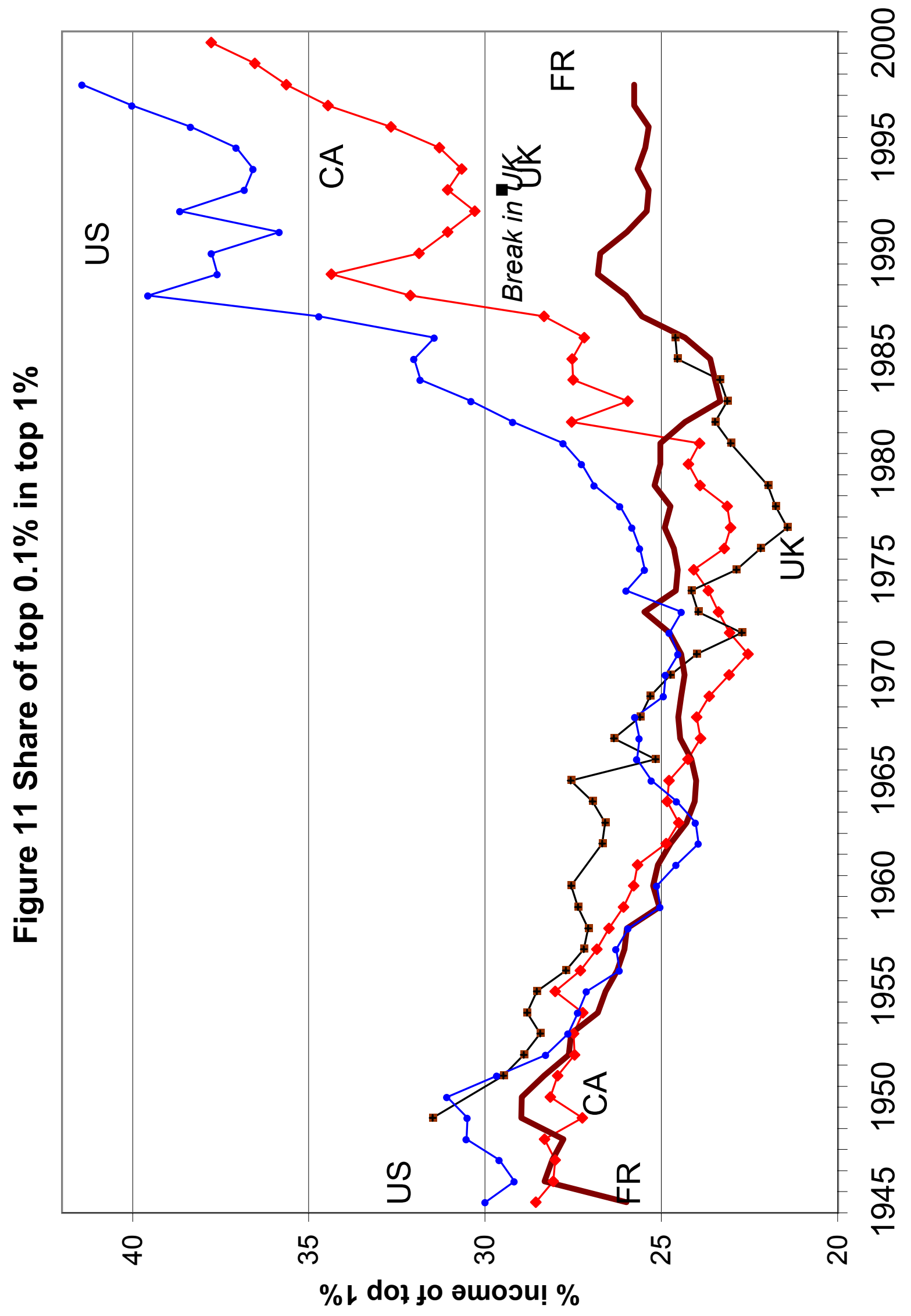




\section{Data Sources}

Figure 1:

B Brandolini, 1998, Table A1, col 1a.

C Budd, 1970, page 255.

E U.S. Census Bureau, 2002, Table A-2.

Figure 2:

B Royal Commission on the Distribution of Income and Wealth (RCDIW), 1979, page 165.

C Atkinson and Micklewright, 1992, Table BI.1.

F 1961 to 1974 from RCDIW, 1977, page 247; 1975, 1977, 1979, 1981, 1983, 1985-1987 from Office for National Statistics, Economic Trends (ET), May 1990, page 118; 1976, 1978 and 1980 from ET, January 1982, page 105; 1982 from ET, November 1983, page 87; 1984 from ET, July 1986, page 103.

G and J 1977 from ET, March 1997, page 53; 1978 to 1993 from ET, May 2002, page 72 .

$\mathrm{H}$ and K ET, May 2002, page 72.

I 1961 to 1974 from RCDIW, 1977, page 249; 1980 from ET, January 1982, page 100; otherwise as F.

L 1961-1991 from Goodman and Webb, 1994, page A2; 19921999/2000 from Clark and Goodman, 2001, Figure 2.

Figure 3:

B, D and K 1971-1979 from Statistics Canada, 1996, page 34; 1980-1999 from Statistics Canada, 2001, Table 705.

E Wolfson, 1986, page 348.

Figure 4

D and F Up to 1995 from Statistics Sweden, 1999, page 3; 1996-1999 from Statistics Sweden, 2001, page 3.

J Gustafsson and Uusitalo, 1990, page 85.

K 1991 to 1995 Eriksson and Pettersson, 2000, page 173; 1996-1999

from Statistics Sweden, 2001, page 3.

Figure 5:

B Income Distribution Survey, http://www.ssb.no/english/subjects/05/01/incdist/main.html

E Bojer, 1987, page 251; 1973, 1976 and 1979 from Bye and

Høyland, 1981.

H Ringen, 1991, page 6.

J Ringen, 1991, page 9.

Figure 6:

Uusitalo, 2001, page 4; 1987 onwards from Statistics Finland website:

http://tilastokeskus.fi/tk/el/tulo/gini.html. 
Figure 7:

B Brandolini, 1998, Table A9.

C supplied by Central Bureau of Statistics, June 1999.

D and E Trimp, 1996, page 32.

Figure 8:

B 1950-1968 from DIW, 1973, page 224; 1970-3 from DIW, 1974, page 312; 1975 onwards from Guger, 1989, Chart 1.

$\mathrm{C}$ and D Hauser and Becker, 2001, page 89.

$\mathrm{E}$ and $\mathrm{F} \quad$ SOEP results supplied by $\mathrm{G}$ Wagner, Tabelle $1 \mathrm{~b}$ (see Becker et al, 2003, but note that the results here apply an equivalence scale equal to the square root of household size).

Figure 9:

$\mathrm{B}$ and $\mathrm{C} \quad$ supplied by Bank of Italy.

D, E and F Brandolini, 1999, page 227.

Figure 10 and 11:

Canada: Saez and Veall, 2002, Table B1.

France: Piketty, 2001, pages 620-1.

UK: sources described in Atkinson, 2002.

US: Piketty and Saez, 2001, Table A1. 


\section{References}

Akerlof, G A, 1980, "A Theory of Social Custom, of which Unemployment may be one Consequence", Quarterly Journal of Economics, vol 95: 749-775.

Alderson, A S and Nielsen, F, 2002, "Globalization and the Great U-Turn: Income Inequality Trends in 16 OECD Countries", American Journal of Sociology, vol 107:1244-1299.

Atkinson, A B, 1997, "Bringing Income Distribution in from the Cold", Economic Journal, vol 107: 297-321.

Atkinson, A B, 1998, Poverty in Europe, Basil Blackwell, Oxford.

Atkinson, A B, 1999, Is Rising Income Inequality Inevitable?, WIDER Annual Lecture 3.

Atkinson, A B, 2002, "Top Incomes in the United Kingdom over the Twentieth Century", Discussion Paper in Economic and Social History, No 43, University of Oxford.

Atkinson, A B, and Brandolini, A, 2001, "Promise and Pitfalls in the Use of "Secondary" Data-Sets: Income Inequality in OECD Countries", Journal of Economic Literature, vol 34: 771-799.

Atkinson, A B and Harrison, A J, 1978, Distribution of Personal Wealth in Britain, Cambridge, Cambridge University Press.

Atkinson, A B and Micklewright, J, 1992, Economic Transformation in Eastern Europe and the Distribution of Income, Cambridge, Cambridge University Press.

Atkinson, A B, Rainwater, L and Smeeding, T M, 1995, Income Distribution in OECD Countries, Evidence from the Luxembourg Income Study, Paris, OECD.

Becker, I, Frick, J R, Grabka, M M, Hauser, R, Krause, P, and Wagner, G G, 2003, "A Comparison of the Main Household Income Surveys for Germany: EVS and SOEP" in R Hauser and I Becker, editors, Reporting on Income Distribution and Poverty, Springer Verlag, Berlin.

Bojer, H, 1987, "Personlig inntektsfordeling i Norge 1970-1984, Tidsskrift for Sammfunnsforskning, vol 28: 247-258.

Brandolini, A, 1998, “A Bird's-Eye View of Long-Run Changes in Income Inequality”, Temi di discussione, Banca d'Italia.

Brandolini, A, 1999, “The Distribution of Personal Income in Post-War Italy: Source Description, Data Quality, and the Time Pattern of Income Inequality", Giornale degli Economisti e Annali di Economia, vol. 58: 183-239, and Temi di discussione Number 350, Banca d'Italia. 
Bresnahan, T F, 1999, "Computerisation and wage dispersion", Economic Journal, vol 109: F390-F415.

Budd, E C, 1970, "Postwar Changes in the Size Distribution of Income in the U.S.", American Economic Review Papers and Proceedings, 1970, vol 60: 247-60.

Bye, T and Høyland, T E, 1981, Inntektsbegreper - inntektsfordeling, Rapport $81 / 31$, Statistisk Sentralbyrå (Central Bureau of Statistics of Norway).

Champernowne, D G, 1973 (originally written in 1936), The Distribution of Income between Persons, Cambridge University Press, Cambridge.

Clark, T and Goodman, A, 2001, "Living Standards under Labour", IFS election briefing note number 4, Institute for Fiscal Studies, London.

Cornia, G A and Court, J, 2001, "Inequality, Growth and Poverty in the Era of Liberalization and Globalization", UNU/WIDER Policy Brief No 4, WIDER, Helsinki.

Davis, D R, 1998, "Does European Unemployment Prop Up American Wages?

National Labor Markets and Global Trade", American Economic Review, vol 88: 478-494.

DIW (Deutsche Institut für Wirtschaftsforschung), 1973, "Einkommensverteilung und -schichtung der privaten Haushalte in der Bundesrepublik Deutschland 1950 bis 1970", Wochenbericht, No 25, Berlin.

DIW (Deutsche Institut für Wirtschaftsforschung), 1974, "Das Einkommen sozialer Gruppen in der Bundesrepublik Deutschland im Jahre 1973", Wochenbericht, No 35, Berlin.

Erikson, R and Goldthorpe, J H, 2002, "Intergenerational Inequality: A Sociological Perspective", Journal of Economic Perspectives, vol 16, no 3: 31-44.

Eriksson, I and Pettersson, T, 2000, "Income Distribution and Income MobilityRecent Trends in Sweden" in R Hauser and I Becker, editors, The Personal Distribution of Income in an International Perspective, Springer, Berlin, pages 158-175.

Expert Group on Household Income Statistics (The Canberra Group), 2001, Final Report and Recommendations, Ottawa.

Flora, P, Kraus, F and Pfenning, W, 1987, State, Economy and Society in Western Europe 1815-1975, Volume II, Frankfurt, Campus Verlag.

Förster, M, 2000, “Trends and Driving Factors in Income Distribution and Poverty in the OECD Area", Labour Market and Social Policy Occasional Papers 42.

Fritzell, J, 1993, "Income Inequality Trends in the 1980s: A Five-Country Comparison", Acta Sociologica, vol 36: 47-62. 
Galbraith, J K, 1998, Created Unequal, The Free Press, New York.

Gardiner, K, 1997, “A survey of income inequality over the last twenty years - how does the UK compare?" in P Gottschalk, B Gustafsson and E Palmer, editors, Changing Patterns in the Distribution of Economic Welfare, Cambridge University Press, Cambridge, 36-59.

Goodman, A and Webb, S, 1994, For Richer, For Poorer, Institute for Fiscal Studies, Commentary No 42.

Gordon, R and Slemrod, J B, 2000, "Are 'Real' Responses to Taxes Simply Income Shifting Between Corporate and Personal Tax Bases?", in J B Slemrod, editor, Does Atlas Shrug?, Harvard University Press, Cambridge.

Gottschalk, P and Smeeding, T M, 1997, "Cross-National Comparisons of Earnings and Income Inequality”, Journal of Economic Literature, vol 35: 633-87.

Gottschalk, P and Smeeding, T M, 2000, "Empirical Evidence on Income Inequality in Industrial Countries", in A B Atkinson and F Bourguignon, editors, Handbook of Income Distribution, Elsevier, Amsterdam.

Guger, A, 1989, "The Distribution of Household Income in Germany", WIFO Working Papers, no 35, Vienna.

Gustafsson, B, Aaberge, R, Cappelen, A, Pedersen, P J, Smith, N and Uusitalo, H, 1999, "The distribution of income in the Nordic countries: changes and causes" in M Kautto, M Heikkilä, B Hvinden, S Marklund, and N Ploug, editors, Nordic Social Policy, Routledge, London.

Gustafsson, B and Johansson, M, 1999, "In Search of Smoking Guns: What Makes Income Inequality Vary Over Time in Different Countries?", American Sociological Review, vol 64: 585-605.

Gustafsson, B and Uusitalo, H, 1990, "Income Distribution and Redistribution during Two Decades: Experiences from Finland and Sweden" in I Persson, editor, Growing Equality in the Welfare State, Oxford University Press, Oxford.

Harrison, B, and Bluestone, B, 1988, The Great U-Turn, Basic Books, New York.

Hauser, R and Becker, I, 2001, Einkommensverteilung im Querschnitt und im Zeitverlauf 1973-1998, Bundesministerium für Arbeit und Sozialordnung, Bonn.

Jäntti, M and Danziger, S, 2000, "Income Poverty in Advanced Countries", in A B Atkinson and F Bourguignon, editors, Handbook of Income Distribution, Elsevier, Amsterdam.

Kraus, F, 1981, "The Historical Development of Income Inequality in Western Europe and the United States", in P. Flora and A. J. Heidenheimer (eds.), The 
Development of Welfare States in Europe and America, Transaction Books, New Brunswick, N.J.

Krueger, D and Perri, F, 2002, "Does Income Inequality Lead to Consumption Inequality?”, NBER Working Paper No 9202.

Kuznets, S, 1953, Shares of Upper Income Groups in Income and Savings, National Bureau of Economic Research, New York.

Kuznets, S, 1963, "Quantitative Aspects of the Economic Growth of Nations: VIII. Distribution of Income by Size", Economic Development and Cultural Change, vol 11, No. 2, part II: 1-80.

Lindert, P H, 2000, "Three Centuries of Inequality in Britain and America”, in A B Atkinson and F Bourguignon, editors, Handbook of Income Distribution, Elsevier, Amsterdam.

Lydall, H F, 1959, “The Distribution of Employment Incomes”, Econometrica, vol 27: 110-115.

Lydall, H F, 1968, The Structure of Earnings, Clarendon Press, Oxford.

Macgregor, D H, 1936, “Pareto’s Law”, Economic Journal, vol 46: 80-87.

Meade, J E, 1964, Efficiency, Equality and the Ownership of Property, Allen and Unwin, London.

Melchior, A, Telle, K and Wiig, H, 2000, "Globalisation and Inequality”, Royal Norwegian Ministry of Foreign Affairs, Studies on Foreign Policy Issues, Report 6B: 2000, Oslo.

Morrisson, C, 2000, "Historical Perspectives on Income Distribution: The Case of Europe" in A B Atkinson and F Bourguignon, editors, Handbook of Income Distribution, Elsevier, Amsterdam.

Neary, J P, 2001, “Competition, Trade and Wages”, Research Paper 2001/03, Globalisation and Labour Markets Programme, University of Nottingham.

Office for National Statistics, various years, "The Effects Of Taxes And Benefits On Household Income", Economic Trends.

Oslington, P, 1998, "Factor market linkages in a global economy", Discussion Paper, University of Oxford.

Pen, J, 1971, Income Distribution, Allen Lane, London.

Pen, J, 1979, "A Clear Case of Leveling: Income Equalization in the Netherlands", Social Research, vol 46: 682-694.

Phelps Brown, H, 1977, The Inequality of Pay, Oxford University Press, Oxford. 
Piketty, T, 2001, Les hauts revenus en France au $20^{\text {ème }}$ siècle, Grasset, Paris.

Piketty, T and Saez, E, 2001, "Income Inequality in the United States, 1913-1998”, NBER Discussion Paper forthcoming.

Reder, M W, 1962, "WAGES: Structure". International Encyclopedia of the Social Sciences, Macmillan, New York, vol 16: 403-414.

Ringen, S, 1991, "Households, Standard of Living, and Inequality", Review of Income and Wealth, vol 37: 1-13.

Roberti, P, 1974, "Income Distribution: A Time-Series and a Cross-Section Study", Economic Journal, vol 84: 629-38.

Rosen, S, 1981, "The Economics of Superstars", American Economic Review, vol 71: 845-858.

Royal Commission on the Distribution of Income and Wealth, 1977, Report 5. Third Report on the Standing Reference, London, HMSO.

Royal Commission on the Distribution of Income and Wealth, 1979, Report 7. Fourth Report on the Standing Reference, HMSO, London.

Saez, E and Veall, M, 2002, "The Evolution of High Incomes in Canada, 19202000", discussion paper.

Sawyer, M, 1976, "Income Distribution in OECD Countries", OECD Economic Outlook, Occasional Studies, Paris, OECD.

Schelling, T C, 1978, Micromotives and Macrobehavior, Norton, New York.

Simon, H, 1957, “The Compensation of Executives”, Sociometry, vol 20: 32-35.

Statistics Canada, 1996, Income after tax, distributions by size in Canada, 1994, Statistics Canada, Ottawa.

Statistics Canada, 2001, Income Trends in Canada 1980-1999, CD-Rom 13F0022XCB, Statistics Canada, Ottawa.

Statistics Canada, 2002, Income Trends in Canada 1980-1999 User's Guide, Income Statistics Division, Statistics Canada, Ottawa.

Statistics Norway, 1993, Inntekts- og Formuesstatistikk 1982, 1984-1990, (Income and Property Statistics 1982, 1984-1990), Oslo

Statistics Sweden, 1999, "Income distribution survey in 1997”, Statistiska meddelanden, If 21 SM 9901, Stockholm. 
Statistics Sweden, 2001, "Income distribution survey in 1999”, Statistiska meddelanden, If 21 SM 0101, Stockholm.

Stark, T, 1977, The Distribution of Income in Eight Countries, Royal Commission on the Distribution of Income and Wealth, Background Paper, No 4, London, HMSO.

Stiglitz, J E, 1969, "Distribution of income and wealth among individuals", Econometrica, vol 37: 382-397.

Trimp, L, 1996, “Inkomens 1959-1994”, Sociaal-Economische Maandstatistiek, vol 13, December: 31-34.

U.S. Census Bureau, 2002, Money Income in the United States: 2001, Current Population Reports, Series P-60, No. 218, Washington, D.C., U.S. Government Printing Office.

Uusitalo, H, 2001, "Changes in Income Distribution during a Deep Recession and After”, Central Pension Security Institute, Helsinki.

van Zanden, J L, 1998, "The Egalitarian Revolution of the $20^{\text {th }}$ Century" in L Soltow and J L van Zanden, editors, Income and Wealth Inequality in the Netherlands $16^{\text {th }}-20^{\text {th }}$ Century, Het Spinhuis, Amsterdam, 175-191.

Vaughan, R N, 1978, "Savings behaviour and the distribution of wealth", paper presented at the European Meeting of the Econometric Society, Geneva.

Vaughan, R N, 1979, "Class Behaviour and the Distribution of Wealth", Review of Economic Studies, vol 46: 447-465.

Webb, J, 2002, “Always With Us? The Evolution of Poverty in Britain 1886-2002”, thesis presented for D Phil, Nuffield College, Oxford.

Weinberg, D H, 1996, “A Brief Look at Postwar U.S. Income Inequality”, Current Population Reports, P60-191, U.S. Census Bureau, Washington, D.C.

Wolfson, M C, 1986, "Stasis Amid Change - Income Inequality in Canada 19651983", Review of Income and Wealth, vol 32: 337-69. 


\title{
CESifo Working Paper Series
}

\author{
(for full list see www.cesifo.de)
}

815 Rainer Niemann and Dirk Simons, Costs, Benefits, and Tax-induced Distortions of Stock Option Plans, December 2002

816 Jan-Egbert Sturm and Barry Williams, Deregulation, Entry of Foreign Banks and Bank Efficiency in Australia, December 2002

817 V. Anton Muscatelli, Patrizio Tirelli, and Carmine Trecroci, Monetary and Fiscal Policy Interactions over the Cycle: Some Empirical Evidence, December 2002

818 Claude Hillinger, A General Theory of Price and Quantity Aggregation and Welfare Measurement, December 2002

819 Erkki Koskela and Ronnie Schöb, Optimal Capital Taxation in Economies with Unionised and Competitive Labour Markets, December 2002

820 Sheilagh Ogilvie, Guilds, Efficiency, and Social Capital: Evidence from German ProtoIndustry, December 2002

821 Hans Gersbach and Verena Liessem, Financing Democracy, December 2002

822 Costas Hadjiyiannis, Panos Hatzipanayotou, and Michael S. Michael, Optimal Tax Policies with Private-Public Clean-Up, Cross-Border Pollution and Capital Mobility, December 2002

823 François Ortalo-Magné and Sven Rady, Homeownership: Low Household Mobility, Volatile Housing Prices, High Income Dispersion, December 2002

824 Syed M. Ahsan and Panagiotis Tsigaris, Measuring the Social Discount Rate under Uncertainty: A Methodology and Application, December 2002

825 Kai A. Konrad, Altruism and Envy in Contests: An Evolutionarily Stable Symbiosis, December 2002

826 Robert S. Chirinko and Huntley Schaller, A Revealed Preference Approach to Understanding Corporate Governance Problems: Evidence from Canada, December 2002

827 Geir B. Asheim, Green National Accounting for Welfare and Sustainability: A Taxonomy of Assumptions and Results, December 2002

828 Andrea Gebauer, Chang Woon Nam, and Rüdiger Parsche, Lessons of the 1999 Abolition of Intra-EU Duty Free Sales for Eastern European EU Candidates, December 2002 
829 Giacomo Corneo, Work and Television, December 2002

830 Vivek H. Dehejia and Yiagadeesen Samy, Trade and Labour Standards - Theory, New Empirical Evidence, and Policy Implications, December 2002

831 Geir B. Asheim and Wolfgang Buchholz, A General Approach to Welfare Measurement through National Income Accounting, December 2002

832 Aaron Tornell and Frank Westermann, The Credit Channel in Middle Income Countries, January 2003

833 Gebhard Flaig, Time Series Properties of the German Monthly Production Index, January 2003

834 Campbell Leith and Jim Malley, Estimated Open Economy New Keynesian Phillips Curves for the G7, January 2003

835 Burkhard Heer and Bernd Süssmuth, Inflation and Wealth Distribution, January 2003

836 Erkki Koskela and Leopold von Thadden, Optimal Factor Taxation under Wage Bargaining - A Dynamic Perspective, January 2003

837 Carola Grün and Stephan Klasen, Growth, Income Distribution, and Well-Being: Comparisons across Space and Time, January 2003

838 Robert S. Chirinko and Ulf von Kalckreuth, On the German Monetary Transmission Mechanism: Interest Rate and Credit Channels for Investment Spending, January 2003

839 Sascha O. Becker, Andrea Ichino, and Giovanni Peri, How Large is the "Brain Drain" from Italy?", January 2003

840 Albert Berry and John Serieux, All About the Giants: Probing the Influences on Growth and Income Inequality at the End of the $20^{\text {th }}$ Century, January 2003

841 Robert Fenge and Martin Werding, Ageing and the Tax Implied in Public Pension Schemes: Simulations for Selected OECD Countries, January 2003

842 Robert Fenge and Martin Werding, Ageing and Fiscal Imbalances Across Generations: Concepts of Measurement, January 2003

843 Giovanni Andrea Cornia, The Impact of Liberalisation and Globalisation on Income Inequality in Developing and Transitional Economies, January 2003

844 Peter Fredriksson and Per Johansson, Program Evaluation and Random Program Starts, January 2003

845 Bernd Hayo and Matthias Wrede, Fiscal Equalisation: Principles and an Application to the European Union, January 2003

846 Syed M. Ahsan and Jaideep Oberoi, Inequality, Well-being and Institutions in Latin America and the Caribbean, January 2003 
847 Chang Woon Nam and Doina Maria Radulescu, The Role of Tax Depreciation for Investment Decisions: A Comparison of European Transition Countries, January 2003

848 V. Bhaskar and Steinar Holden, Wage Differentiation via Subsidised General Training, January 2003

849 Paloma Lopez-Garcia, Labour Market Performance and Start-up Costs: OECD Evidence, January 2003

850 Christian Keuschnigg and Soren Bo Nielsen, Public Policy for Start-up Entrepreneurship with Venture Capital and Bank Finance, January 2003

851 Yin-Wong Cheung, Menzie D. Chinn, and Eiji Fujii, China, Hong Kong, and Taiwan: A Quantitative Assessment of Real and Financial Integration, January 2003

852 Gregory D. Hess, The Economic Welfare Cost of Conflict: An Empirical Assessment, February 2003

853 Douglas J. Cumming and Jeffrey G. MacIntosh, Comparative Venture Capital Governance. Private versus Labour Sponsored Venture Capital Funds, February 2003

854 Eckhard Janeba and John Douglas Wilson, Decentralization and International Tax Competition, February 2003

855 Tapio Palokangas, Capital Accumulation and Employment Cycles in a Model of Creative Destruction, February 2003

856 Brendan Walsh, When Unemployment Disappears: Ireland in the 1990s, February 2003

857 Luis H. R. Alvarez and Erkki Koskela, A General Approach to the Stochastic Rotation Problem with Amenity Valuation, February 2003

858 Christian Schultz, Strategic Campaigns and Redistributive Politics, February 2003

859 Ernst Fehr and Joseph Henrich, Is Strong Reciprocity a Maladaptation? On the Evolutionary Foundations of Human Altruism, February 2003

860 Haizhou Huang, Dalia Marin, and Chenggang Xu, Financial Crisis, Economic Recovery and Banking Development in Former Soviet Union Economies, February 2003

861 Pedro Cardoso and Bernard M.S. van Praag, How Sustainable Are Old-age Pensions in a Shrinking Population with Endogenous Labour Supply?, February 2003

862 Volker Meier, Efficient Transfer of Aging Provisions in Private Health Insurance, February 2003

863 Edward Castronova, Theory of the Avatar, February 2003 
864 Robert S. Chirinko, Hans van Ees, Harry Garretsen, and Elmer Sterken, Investor Protections and Concentrated Ownership: Assessing Corporate Control Mechanisms in the Netherlands, February 2003

865 Bernard M.S. van Praag and Pedro Cardoso, The Mix Between Pay-as-you-go and Funded Pensions and what Demography has to do with it, February 2003

866 Ernst Fehr, Urs Fischbacher, Bernhard von Rosenbladt, Jürgen Schupp, and Gert G. Wagner, A Nation-Wide Laboratory. Examining Trust and Trustworthiness by Integrating Behavioral Experiments into Representative Survey, February 2003

867 Frank Heinemann, The Inflationary Impact of Wage Indexation, February 2003

868 Eytan Sheshinski, Bounded Rationality and Socially Optimal Limits on Choice in a Self-Selection Model, February 2003

869 M. Hashem Pesaran, Estimation and Inference in Large Heterogenous Panels with Cross Section Dependence, February 2003

870 Luis H. R. Alvarez and Erkki Koskela, On the Tree-Cutting Problem under Interest Rate and Forest Value Uncertainty, February 2003

871 Norbert Berthold and Rainer Fehn, Unemployment in Germany: Reasons and Remedies, February 2003

872 Clemens Fuest, Bernd Huber, and Philipp Tilleßen, Tax Policy and Entrepreneurship in the Presence of Asymmetric Information in Capital Markets, February 2003

873 Eytan Sheshinski, Optimum and Risk-Class Pricing of Annuities, February 2003

874 Willi Leibfritz, Paul O'Brien and Jean-Christophe Dumont, Effects of Immigration on Labour Markets and Government Budgets - An Overview, February 2003

875 M. Hashem Pesaran and Allan Timmermann, How Costly is it to Ignore Breaks when Forecasting the Direction of a Time Series?, February 2003

876 Thorvaldur Gylfason and Gylfi Zoega, Education, Social Equality and Economic Growth: A View of the Landscape, February 2003

877 Robin Boadway and Jean-François Tremblay, Public Economics and Startup Entrepreneurs, February 2003

878 Erkki Koskela and Roope Uusitalo, The Un-Intended Convergence: How the Finnish Unemployment Reached the European Level, February 2003

879 Robert Fenge and Volker Meier, Pensions and Fertility Incentives, February 2003

880 Eytan Sheshinski, Note on Income Taxation and Occupational Choice, February 2003

881 A B Atkinson, Income Inequality in OECD Countries: Data and Explanations, February 2003 